\title{
Hate Speech and Racist Slurs in the South African Context: Where to Start?
}

J Geldenhuys* and M Kelly-Louw**

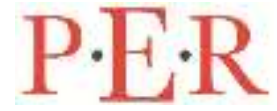

Pioneer in peer-reviewed, open access online law publications

Authors

Judith Geldenhuys

Michelle Kelly-Louw

Affiliation

University of South Africa

Email

geldej@unisa.ac.za

kellym@unisa.ac.za

Date Submission

6 September 2019

Date Revised

4 June 2020

Date Accepted

13 July 2020

Date published

27 July 2020

Editor Prof O Fuo

How to cite this article

Geldenhuys J and Kelly-Louw M "Hate Speech and Racist Slurs in the South African Context: Where to Start?" PER / PELJ 2020(23) DOI

http://dx.doi.org/10.17159/17273781/2020/v23i0a7043

\section{Copyright}

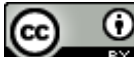

DOI

http://dx.doi.org/10.17159/17273781/2020/v23i0a7043

\begin{abstract}
Protecting people against hate speech and racist slurs requires weighing up several fundamental rights. To maintain legitimacy in enforcing the legislative protection, a fine balance must be struck between the rights to equality and dignity on the one hand and freedom of speech on the other hand. An analysis of the legislative framework ousting hate speech and unfair discrimination on the basis of race and the manner in which the different relevant provisions have been applied by the courts shows that there are discrepancies that must be addressed. Despite the differences between the policy that facilitated the adoption of the Promotion of Equality and Prevention of Unfair Discrimination Act 4 of 2000 and the Employment Equity Act 55 of 1998, an alignment must be achieved in the starting point for an objective enquiry dealing with racism. To excuse serious cases of hate speech perpetrated by one population group while presuming that the other population group is racist from the outset does not promote South Africa's nation-building project. On the flipside, to address the unbalanced method of interpretation and implementation of the legislative provisions by adjusting the vantage point from which the assessment into whether an utterance is racist and derogatory is commenced would advance the constitutional value of non-racialism.
\end{abstract}

\section{Keywords}

Discrimination; freedom of expression; hate speech; racial slurs; racism; unfair discrimination on the basis of race 


\section{Introduction}

In 2016 Penny Sparrow became infamous for posting on Facebook with reference to holiday makers at the beach that she will in future refer to black South Africans as "monkeys". ${ }^{1}$ She was found guilty of hate speech and of crimen injuria and received two harsh sentences. ${ }^{2}$ Shortly thereafter, Vicki Momberg, after being the victim of a smash-and-grab incident, was recorded on video racially abusing the black police officers assisting her. ${ }^{3}$ Momberg was found guilty on four counts of crimen injuria and became the first South African to receive a prison sentence for making a racial utterance. ${ }^{4}$

In contrast, in 2016 Benny Morota referred to white South Africans as cockroaches ${ }^{5}$ and the leader of the Economic Freedom Front (the EFF), Julius Malema, declared that "We are not calling for the slaughter of white people, at least for now...".

Morota's conduct ${ }^{6}$ was subjected to an investigation held by the South African Human Rights Commission (the SAHRC) in 2018. ${ }^{7}$ Notwithstanding, the SAHRC's final report made no reference to Morota's racist slurs. ${ }^{8}$ The

* Judith Geldenhuys. LLB LLM (UP) LLD (Unisa). Associate Professor in the Department of Mercantile Law, Unisa, South Africa. E-mail: geldej@unisa.ac.za. ORCID ID https://orcid.org/0000-0001-9956-7071. We are thankful for the valuable remarks of the reviewers. We remain responsible for any errors.

** $\quad$ Michelle Kelly-Louw. B IURIS LLB LLM LLD (Unisa) Dip Insolvency Law and Practice (SARIPA) (UJ). Professor in the Department of Mercantile Law, Unisa, South Africa. E-mail: kellym@unisa.ac.za. ORCID ID https://orcid.org/0000-0003-0145-3119.

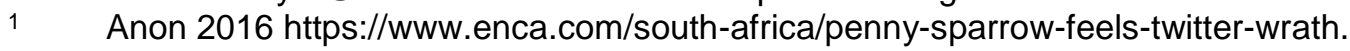

2 The Equality Court ordered Sparrow to pay R150 000 for hate speech. On the basis of crimen injuria she was ordered to pay a fine of R5 000, or to serve a 12-month prison sentence. Anon $2016 \mathrm{https}: / / \mathrm{www}$.enca.com/south-africa/penny-sparrowfeels-twitter-wrath.

$3 \quad$ She had uttered the word "kaffir" (the k-word) no fewer than 48 times.

$4 \quad$ She was sentenced to 3 years in prison, with 1 year suspended. Ramphele 2019 http://www.capetalk.co.za/articles/297688/crime-and-punishment-vicki-momberg-slandmark-sentence-explained.

5 Burger 2016 https://www.netwerk24.com/Nuus/Politiek/ernstig-gewaarsku-oor-witkakkerlakke-20161022; Burger 2016 https://nuus.info/dosent-na-wit-kokkerotte-nogongestraf/; Natasha Stop White Genocide in SA 2016 https://stopwhitegenocideinsareports.blogspot.com/2016/06/black-unisa-lecturerwho-called-white.html.

$6 \quad$ Discussed under 4.1.1.

7 The SAHRC investigated among others individual complaints of hate speech in the University of South Africa. See Geldenhuys 2019 TSAR 640, 654 and 655.

8 Bozzoli 2018 https://www.dailymaverick.co.za/opinionista/2018-11-13-whathappens-when-universities-start-to-decay-the-case-of-unisa/. 
SAHRC ruled that Malema's statement did not qualify as hate speech ${ }^{9}$ in the light of the factual, social and historical context in which the utterance had been made. ${ }^{10}$

Different approaches were followed by the Equality Court in South African Human Rights Commission $v$ Khumalo ${ }^{11}$ (Khumalo) and by the Constitutional Court in Rustenburg Platinum Mine v SAEWA obo Meyer Bester $^{12}$ (Bester CC). Whereas the Equality Court held that it is inappropriate to treat different perpetrators of alleged racism differently from one another based on historic inequities, the Constitutional Court expressed the view that recognition of the country's history of apartheid and its legacy should be the starting point in any inquiry where the alleged perpetrator is white and the victim is black. ${ }^{13}$

A representative of the SAHRC in an interview with the media also recently owned up to the fact that the SAHRC is "purposefully lenient to black offenders in incidents concerning racial utterances made to white victims because of the historical context", and that "racism from whites towards other races was more pervasive". ${ }^{14}$ Whether these views regarding how racist remarks uttered by different population groups must be approached are correct is considered in this contribution.

This article commences with a discussion of the values in the Constitution of the Republic of South Africa, 1996 (the Constitution) that informed the adoption of the protection against hate speech and racial slurs. The Promotion of Equality and Prevention of Unfair Discrimination Act 4 of 2000 (the PEPUDA) provides protection for racist slurs and hate speech outside the workplace and the Employment Equity Act 55 of 1998 (the EEA) provides protection inside the workplace. Therefore, the underlying policy considerations for the enactment of the PEPUDA and the EEA respectively are scrutinised to ascertain whether the distinction that has been drawn between instances when racist slurs are made inside as opposed to outside

9 Jana 2019 https://www.politicsweb.co.za/documents/malemas-white-slaughterremarks-the-sahrcs-finding; also see SAHRC 2019 https://www.sahrc.org.za/home/ 21/files/SAHRC\%20Finding\%20Julius\%20Malema\%20\&\%20Other\%20March\%20 2019.pdf (hereafter SAHRC Findings).

10 SAHRC Findings para 10.

11 South African Human Rights Commission v Khumalo 20191 SA 289 (GJ) (hereafter Khumalo).

12 Rustenburg Platinum Mine v SAEWA obo Bester 20185 SA 78 (CC) (hereafter Bester CC).

13 Bester CC para 48.

14 Hlatshaneni 2019 https://citizen.co.za/news/south-africa/general/2119286/mycombi-court-rant-wasnt-racist-mazibuko-tells-sahrc/. 
the workplace is warranted. The fact that the divide between the consequences that follow if racist utterances are made in the workplace and outside of the employment context has all but disappeared ${ }^{15}$ supports our argument that there should be an alignment between the starting point to the enquiry irrespective of whether the racist slur was uttered inside or outside the workplace. Thereafter, the two different approaches that were recently followed by the Equality Court in Khumalo and by the Constitutional Court in Bester CC and the reasoning for the different courts' findings are set out in order to show the different approaches followed under the PEPUDA and the EEA. The question is posed as to whether a change in the public policy or good morals (boni mores) could explain why historical events should be factored in in the assessment of whether someone is guilty of hate speech or making a racist utterance in some instances and not in others.

It is concluded that leaving serious cases of hate speech and the making of racist slurs unchecked has the effect of entrenching the remaining divisions between different races. Addressing the unbalanced method of interpretation and implementation of the legislative provisions would echo the government's commitment to eradicating inequitable policies based purely on race in the workplace and beyond in accordance with the constitutional value of non-racialism.

\section{The rights in the Constitution and the definition of hate speech}

South Africa has a history of vast inequity along racial lines. Before 1993 a system of parliamentary sovereignty existed, and the South African courts did not have the power to test the validity or fairness of legislation. Parliament adopted several discriminatory and degrading apartheid laws that violated the human rights of the majority of the country's citizens, black South Africans. Apartheid legislation often entrenched discrimination between racial groups both inside and outside the workplace. ${ }^{16}$

15 In recognition of the fact that the dividing line has faded, Botha refers to instances that occurred both in the workplace and on social media. Botha 2018 THRHR 671, 673.

16 These laws included the Suppression of Communism Act 44 of 1950, the Native Laws Amendment Act 54 of 1952 and the Bantu Education Act 47 of 1953. Most of the discriminatory legislation has been repealed. Currie and De Waal Bill of Rights Handbook 227. Also see Du Toit 2006 ILJ 1311. 
In the past racism was institutionalised and legitimised. ${ }^{17}$ An ultimate break with the colonial history took place in 1994 when a new constitutional dispensation came into operation. The Constitution is a deliberate, "radical and decisive break from that part of the past which is unacceptable". ${ }^{18}$ The coming into operation of the Interim Constitution ${ }^{19}$ on 27 April 1994 meant that equal human rights were afforded to all South Africans irrespective of race. ${ }^{20}$ The Constitution acknowledges the deep-rooted societal divisions and the remaining "strife, conflict, untold suffering and injustice". ${ }^{21}$ Therefore, in the context of the Constitution as a whole the Bill of Rights must be read and understood keeping in mind the project of transformation. ${ }^{22}$

Pertinent to the discussion, the Constitution entrenches three pivotal fundamental rights that apply to all citizens. First, the Constitution provides for the right to equality before the law ${ }^{23}$ and prohibits unfair discrimination based on seventeen grounds, one of which is race. ${ }^{24}$ Secondly, the Constitution requires government to enact national legislation in order to oust unfair discrimination and promote the achievement of equality. ${ }^{25}$ Besides the listed grounds, unfair discrimination on unlisted grounds that are inclined to impact negatively on the right to dignity as entrenched in section 10 of the Constitution is also prohibited. ${ }^{26}$ As to the purpose of the protection against unfair discrimination, in President of the Republic of South Africa $v$ Hugo $^{27}$ the Constitutional Court held that it is aimed at the

\footnotetext{
$17 \quad$ Bester CC para 52.

18 Bester CC para 52.

19 Constitution of the Republic of South Africa 200 of 1993.

20 Ackerman 2004 NZ L Rev633. Currie and De Waal Bill of Rights Handbook 2; Bester CC para 52.

$21 \quad S$ v Makwanyane 19943 SA 868 (A) para 262; also see Bester CC para 52.

22 Currie and De Waal Bill of Rights Handbook 1.

23 Section 9(1) of the Constitution of the Republic of South Africa, 1996 (the Constitution).

24 Section 9(3) of the Constitution. The other grounds are "gender, sex, pregnancy, marital status, ethnic or social origin, colour, sexual orientation, age, disability, religion, conscience, belief, culture, language and birth". This right is accessible directly by a victim of hate speech in the absence of other protection in national legislation only. See Institute for Democracy in SA v African National Congress 2005 10 BCLR 995 (C) para 17; Minister of Health v New Clicks SA (Pty) Ltd 20062 SA 311 (CC) para 437. In some cases, direct reliance on $s 9$ of the Constitution has been permitted. See, for instance, Stokwe v MEC, Department of Education, Eastern Cape Province 20058 BLLR 822 (LC).

25 Section 9(4) of the Constitution.

26 Section 10 of the Constitution. Also see Botha 2018 THRHR 672-673.

27 President of the Republic of South Africa v Hugo 1998 JOL 1543 (CC) (hereafter Hugo) para 41.
} 
achievement of a position where all human beings are afforded "equal dignity and respect, regardless of their membership of particular groups."28

The right to dignity is of direct relevance to the protection afforded against racist slurs and utterances. The majority ${ }^{29}$ in Canada (Human Rights Comm.) $v$ Taylor ${ }^{30}$ held that "...messages of hate propaganda undermine the dignity and self-worth of target group members and, more generally, contribute to disharmonious relations among various racial, cultural and religious groups, as a result eroding the tolerance and open-mindedness that must flourish in a multi-cultural society which is committed to the idea of equality." ${ }^{31}$ In $S v$ Makwanyane ${ }^{32} \mathrm{O}^{\prime}$ Regan $\mathrm{J}$ recognised the protection of human dignity as the "touchstone of the new political order."33 Consequently, the necessity for the inclusion of the protection against racial slurs and hate speech for all race groups is widely acknowledged. The Constitution also entrenches the right to access to justice. ${ }^{34}$ This right is not applied differently in respect of different population groups.

Upon its enactment, section 10(1) of the PEPUDA, which regulated hate speech, provided that, subject to the proviso in section $12,{ }^{35}$ no person could publish, propagate, advocate or communicate words based on one or more of the prohibited grounds (e.g. race, gender, sex, ethnic or social origin, colour, sexual orientation, belief, culture, and language) ${ }^{36}$ against any person, that could reasonably be interpreted to demonstrate a clear intention:

(a) to be hurtful;

(b) to be harmful or to incite harm; or

$28 \quad$ Hugo para 41.

29 Dickson CJ (as he was) wrote the judgment. Wilson, L'Heureux-Dub and Gonthier JJ concurred.

$30 \quad$ Canada (Human Rights Comm.) v Taylor 199013 CHRR D/435 (SCC).

31 Canada (Human Rights Comm.) v Taylor 199013 CHRR D/435 (SCC) paras 28-29.

$32 \quad S$ v Makwanyane 19953 SA 391 (CC) para 329.

33 Currie and De Waal Bill of Rights Handbook 250-253.

34 Section 34 of the Constitution reads: "Everyone has the right to have any dispute that can be resolved by the application of law decided in a fair public hearing before

35 The rider in $\mathrm{s} 12$ of the Promotion of Equality and Prevention of Unfair Discrimination Act 4 of 2000 (PEPUDA) excludes "bona fide engagement in artistic creativity, academic and scientific inquiry, fair and accurate reporting in the public interest or publication of any information, advertisement or notice in accordance with $s 16$ of the Constitution" from the scope of $s$ 10(1) of the PEPUDA.

For a list of the prohibited grounds, see $s 1$ of the PEPUDA. 
(c) to promote or propagate hatred.

During November 2019 the Supreme Court of Appeal in Qwelane v South African Human Rights Commission and Another ${ }^{37}$ held that section 10(1) of the PEPUDA was unconstitutional for want of compliance with section 16 of the Constitution. ${ }^{38}$ Accordingly, the court ordered that Parliament must within eighteen months of the ruling amend the wording of section 10(1) of the PEPUDA in order to remedy the defect. ${ }^{39}$ The Supreme Court of Appeal ordered that the interim definition of "hate speech" as envisaged in section 10(1) the PEPUDA is to "advocate hatred... based on race, ethnicity, gender, religion or sexual orientation... that constitutes incitement to cause harm."40

Section 16 of the Constitution guarantees the right to freedom of speech. What constitutes hate speech is restricted in the sense that "bona fide engagement in artistic creativity, academic and scientific inquiry, fair and accurate reporting in the public interest or publication of any information, advertisement or notice in accordance with the right to freedom of speech in section 16 of the Constitution, is not considered to be hate speech." ${ }^{41}$ The rationale for excluding certain utterances from the protection against hate speech in the PEPUDA is to allow for meaningful dialogue on sensitive issues. The ability to speak freely is important to overcome the racial divides. ${ }^{42}$ But certain types of utterances could potentially cause harm and impinge on the right to dignity. ${ }^{43}$ Therefore, the right to freedom of speech is not absolute. A restriction of the right can be justified only in terms of

37 Qwelane v South African Human Rights Commission 20202 SA 124 (SCA) (hereafter Qwelane SCA).

38 See Qwelane SCA paras 1, 36 and 96. The ruling has since been referred to the Constitutional Court (CCT case number 13/2020) for confirmation and was to be heard on 7 May 2020. See Southern Africa Litigation Centre 2020 https://www.southernafricalitigationcentre.org/2020/04/28/jonathan-dubulaqwelane-v-south-african-human-rights-commission-and-another/. Qwelane SCA para 96. Notably, should Parliament fail to draft an amendment within the 18 months stipulated by the court, the interim amendment will become final. Section 10(1) of the PEPUDA as amended in the interim.

41 Section 10 read with $s 12$ of the PEPUDA.

42 Friedman 2000 Ecquid Novi 267, 268; Hotz v University of Cape Town 20172 SA 485 (SCA) para 67; Khumalo 2018 SA Merc LJ 394.

$43 \quad$ Islamic Unity Convention Independent Broadcasting Authority 20024 SA 294 (CC) paras $31-33,45$. 
section 36 of the Constitution, ${ }^{44}$ in which case the infringement is considered a "justifiable infringement". 45

An important constitutional right that applies in the employment context, is the right to fair labour practices. This fundamental right has the effect of subjecting all conduct in the workplace to a fairness evaluation. No definition of "hate speech" is provided in the EEA. As to the protection offered against racial discrimination ${ }^{46}$ in the EEA in the context of the relevant rights in the Constitution, the situation is as follows. The EEA prohibits direct or indirect discrimination on the basis of race, among other grounds. ${ }^{47}$ Notably, these listed grounds are narrowly aligned with the right to equality in the Constitution. ${ }^{48}$ There are two express exclusions in the EEA where the discriminatory conduct would not be recognised as unfair discrimination, i.e. if it is proven to be an inherent requirement of the job, ${ }^{49}$ or part of a carefully designed affirmative action measure. ${ }^{50}$ The affirmative action exclusion in the EEA is also in harmony with the exclusion enumerated in the Constitution. ${ }^{51}$

44 Section 16 read with s 36 of the Constitution; Islamic Unity Convention v Independent Broadcasting Authority 20024 SA 294 (CC) paras 10 and 12. Also see Currie and De Waal Bill of Rights Handbook 353-354.

45 Currie and De Waal Bill of Rights Handbook 151.

46 This would apply in the context of racial slurs made in the employment context. "Racial slurs" for the purposes of this contribution advocate hatred based on race. This is derived from the distinction drawn by the equality court in Khumalo para 82 between a "racist remark" and hate speech as envisaged in the PEPUDA.

47 Section 6 of the Employment Equity Act 55 of 1998 (the EEA).

48 Compare s 6(3) of the EEA and s 9 of the Constitution. The EEA enumerates as prohibited grounds of discrimination the following: Race, gender, sex, pregnancy, marital status, family responsibility, ethnic or social origin, colour, sexual orientation, age, disability, religion, HIV status, conscience, belief, political opinion, culture, language and birth or on any other arbitrary ground. In $s$ 9(3) the Constitution lists as prohibited grounds "race, gender, sex, pregnancy, marital status, ethnic or social origin, colour, sexual orientation, age, disability, religion, conscience, belief, culture, language and birth."

49 Section $6(2)(b)$ of the EEA.

50 Section 6(2)(a) of the EEA.

51 Section 9(2) of the Constitution determines that "[t]o promote the achievement of equality, legislative and other measures designed to protect or advance persons, or categories of persons, disadvantaged by unfair discrimination may be taken." 


\section{Different approaches inside and outside of employment}

\subsection{Introduction}

Two different pieces of legislation apply ${ }^{52}$ to racist slurs ostensibly made applicable based on whether the utterance was made inside or outside the workplace: the PEPUDA applies outside the workplace, and the EEA inside. However, even if a racist slur is uttered outside of the workplace, employers often discipline, warn or even dismiss employees. ${ }^{53}$

We acknowledge unfair discrimination and hate speech as two separate legal concepts. The difference between a racist remark and hate speech lies in the fact that in the case of hate speech, the utterance contains a factor of "incitement". ${ }^{4}$ The test for hate speech is whether the utterance "... could be reasonably construed to demonstrate a clear intention to incite harm." 55 The test to establish that unfair discrimination had occurred differs significantly. In order to assess whether discrimination amounts to unfair discrimination as envisaged in the EEA, the two-pronged test that was laid down in Harksen $v$ Lane $^{56}$ is applied. First, it is determined whether the differentiation constitutes "discrimination", and then the fairness is assessed. Whereas mens rea is not a requirement to hold the utterer liable for hate speech in terms of PEPUDA, claims of alleged racism apparently can be countered by raising a lack of intention to harm the victim. ${ }^{57}$ Whereas the PEPUDA states that in hate speech the fairness or otherwise of the conduct is not assessed, ${ }^{58}$ in terms of the EEA, the assessment of whether the perpetrator is guilty of racism has to do with fairness.

The Equality Court in the hate speech case in Khumalo and the Constitutional Court in the unfair dismissal case concerning a racial utterance, in Bester CC, followed different approaches in factoring in the historical context. Both ratios provide valuable insights.

52 The PEPUDA and the EEA. The Prevention and Combating of Hate Crimes and Hate Speech Bill has not yet been adopted and is not discussed here. See Prevention and Combating of Hate Crimes and Hate Speech Bill B9-2018 and the Explanatory Summary (Gen N 167 in GG 41543 of 29 March 2018). Botha and Govindjee 2017 PELJ 3-8 point out that the tests for hate speech and unfair discrimination differ from each other significantly and that to conflate the concepts is problematic.

$54 \quad$ Khumalo para 82; Qwelane SCA para 96.

$55 \quad$ Khumalo para 88; Qwelane SCA para 96.

$56 \quad$ Harksen $v$ Lane 19981 SA 300 (CC).

57 Botha and Govindjee 2017 PELJ 6-11.

58 The heading of $s 15$ of PEPUDA reads "Hate speech and harassment not subject to determination of fairness." 
In the hate speech case under the PEPUDA the salient facts were as follows. Khumalo, a State Official employed by the Gauteng Provincial Government as a Sports Officer, had outside his workplace on a social media platform on 4 January 2016 posted the following utterance while participating in an online debate:

I want to cleans [sic] this country of all white people. we must act as Hitler did to the Jews. I don't believe any more that the [sic] is a large number of not so racist white people. I'm starting to be skeptical even of those within out [sic] Movement of the ANC. I will from today unfriend all white people I have as friends from today u must be put under the same blanket as any other racist white because secretly $u[s i c]$ all are a bunch of racist $f^{\star * *}$ heads. as we have already seen $[s i c]$.

Noo [sic] seriously though u oppressed us when $u$ [sic] were a minority and then manje u call us monkeys and we suppose to let it slide. white people in south Africa [sic] deserve to be hacked and killed like Jews. U have the same venom moss. look at Palestine. noo u must be bushed alive and skinned and your off springs used as garden fertilizer $[\mathrm{sic}]{ }^{59}$

The equality court per Sutherland $J$, in assessing whether the utterance constituted hate speech as provided for in section 10 of the PEPUDA in its original formulation, among other things considered the significance of the utterance at the time that it was made in the light of racial sensitivities in the country. ${ }^{60}$ The SAHRC, which had brought the application to declare the utterance hate speech before the equality court, in its replying affidavit had provided information about the violence perpetrated against whites in South Africa, and the current vulnerability of this minority group. Moreover, in the affidavit a brief exposition was provided by the SAHRC regarding antiSemitism, along with an explanation that there are descendants of Holocaust victims residing in South Africa. ${ }^{61}$

The court stressed that the test for hate speech was whether Khumalo's utterance "could be reasonably construed to demonstrate a clear intention to 'incite harm"'. ${ }^{62}$ The test is purely objective and the subjective intention of the utterer is irrelevant. ${ }^{63}$ Accordingly, the standard of the reasonable person as applied in reference to section 10(1) of the PEPUDA is as follows:

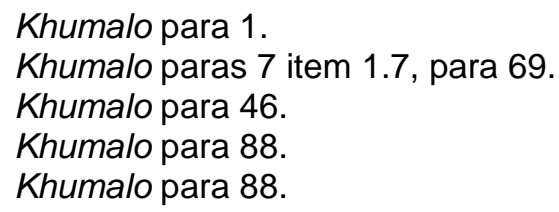


... whether a reasonable person could conclude (not inevitably should conclude) that the words mean the author had a clear intention to bring about the prohibited consequences. ${ }^{64}$

As to the contents of the statement, the court noted that the meaning of Khumalo's utterance was patent. ${ }^{65}$ The statement legitimises violence towards white South Africans. ${ }^{66}$ It suggested that whites ought to be "ostracised, marginalised, excluded, indeed, totally 'othered', dehumanised, and legitimately be subjected to violence."67

One of the questions that the Equality Court in Khumalo considered was whether different segments of the South African population should be treated differently in the manner in which alleged hate speech is treated. 68 In his testimony Khumalo had given an account of his childhood, of growing up under apartheid in poverty, and of the acts of racism that he had experienced. ${ }^{69}$ The amicus curiae ${ }^{70}$ in Khumalo had also considered Khumalo's social context in the light of a report from a psychologist ${ }^{71}$ which noted the lived experience of a black South African who grew up in apartheid. ${ }^{72}$ Khumalo argued that his life experience justified his reaction to the late Sparrow's utterance on social media in which she likened black people to monkeys. ${ }^{73}$ Khumalo testified that he understood Sparrow's post to say that "the crowd of Blacks on the beach made it dirty". ${ }^{74} \mathrm{He}$ indicated that he felt that being likened to a "monkey" was akin to being called the kword. Khumalo indicated that he was upset by the fact that Sparrow was getting support from "a significant amount of white people" who argued that Sparrow was merely exercising her right to freedom of speech. ${ }^{75}$

The Equality Court held that it would not be possible to overcome the rift between different races in South Africa if black South Africans on the one

\footnotetext{
$64 \quad$ Khumalo paras 88 and 90.

$65 \quad$ Khumalo para 91.

$66 \quad$ Khumalo para 91.

$67 \quad$ Khumalo para 91

$68 \quad$ Khumalo para 101.

$69 \quad$ Khumalo para 31.

$70 \quad$ Khumalo para 8. Volunteered by the Legal Resources Centre.

$71 \quad$ Khumalo para 47.

$72 \quad$ Khumalo para 48.

73 Compare $R$ v Malik 19681 All ER 582. In Malik a black perpetrator was charged for saying that whites are "vicious and nasty people" and for referring to them as "white monkeys". Moreover, he stated that any white man who lays hands on a black woman should be killed. He unsuccessfully sought to rely on the fact that he had suffered discrimination and intolerance by whites. Also see Rosenfeld Hate Speech in Constitutional Jurisprudence 23-24.

$74 \quad$ Khumalo para 29.

$75 \quad$ Khumalo para 32.
} 
hand are "licensed to be condemnatory because its members were the victims of oppression" and whites, on the other hand "are disciplined to remain silent". ${ }^{76}$ Section 10 of the PEPUDA is intended to promote social cohesion. ${ }^{77}$ To "other" a racial group contradicts the Constitution. ${ }^{78}$ Instead of promoting social cohesion, applying the hate speech provision inconsistently could result in "spiralling invective"79 or even worse, racial genocide. ${ }^{80}$

The Equality Court in Khumalo did not by its finding determine that the historical context should be ignored insofar as incidents of hate speech are concerned. Personal social circumstances and historical context, ${ }^{81}$ together with other surrounding circumstances, ought to be considered as factors which aggravate or mitigate the likelihood of incitement to cause harm and which contribute towards establishing what punishment the perpetrator should ultimately receive. ${ }^{82}$

In contrast, the Constitutional Court ${ }^{83}$ in Bester CC was required to decide whether calling a fellow employee in the workplace a "swart man" (black man) constituted racism rendering Bester's dismissal fair. He had stated: "verwyder daardie swart man se voertuig" (remove that black man's vehicle). The arbitrator in the Commission for Conciliation, Mediation and Arbitration (the CCMA) had ruled that the utterance was racially inoffensive. On review, the Labour Court considered the following facts: at the time of making the utterance Bester was aggressive. He had pointed his finger at the alleged victim and spoken in a loud voice. The incident occurred during a meeting. The Labour Court was not convinced that Bester, as found by the CCMA commissioner, had used the term "swart man" benignly to identify the victim that he did not know. In the Labour Court's view, the context suggested that Bester's utterance was derogatory and racist. ${ }^{84}$

In a subsequent appeal the Labour Appeal Court emphasised that the words must be looked at in the context in which they were uttered. In this instance

\footnotetext{
$76 \quad$ Khumalo para 100.

$77 \quad$ Khumalo para 103.

$78 \quad$ Khumalo para 103.

79 One of the forms of harm that was accepted to exist in Khumalo is responding in kind to utterances inciting hatred and contempt.

80 Khumalo para 101.

81 Khumalo paras 101-102.

$82 \quad$ Khumalo para 103.

83 Zondo ACJ, Kollapen and Zondi AJJ and Madlanga, Mhlantla, Jafta, Theron, Froneman and Cameron JJ. The judgment as penned down by Theron $\mathrm{J}$ was unanimous. Notably, the justices were representative in terms of race. 
the term was a neutral phrase unless the opposite was proven by means of contextual evidence. ${ }^{85}$ The court explained that a prima facie neutral phrase can attract a pejorative or a laudatory meaning depending on the context. ${ }^{86}$ If the term had been used by a black person to refer to another black person, it would be neutral. But, if it were not a black person who made the utterance, the term could lose its neutrality. ${ }^{87}$ The Labour Appeal Court felt that on the facts it was equally plausible that Bester in the context had used the words to describe the person who was parked next to him, whose name he did not know. ${ }^{88}$

But the Constitutional Court in the final appeal in Bester CC disagreed with the Labour Appeal Court's stance that a racial descriptor starts off as being neutral. The highest court expressed the view that following this approach ignores the impact that apartheid had, and that South Africa remains a racially charged environment in which racist views are still the prevailing view. ${ }^{89}$ The most recent statistics confirm the contrary. ${ }^{90}$ It corroborates the findings of the $\operatorname{IRR}^{91}$ that recently more white South Africans experience racism than blacks do. ${ }^{92}$ Notwithstanding, the highest court held that if a white person uses the racial descriptor "black man", the starting view should be that it is racist, because South Africa's historical context dictates this approach. The Constitutional Court noted that the Labour Appeal Court had "sanitised" the use of the word "swart man" because the court had erroneously ignored that racial descriptors in post-apartheid South Africa are not neutral. ${ }^{93}$ By ignoring the historical context, the Constitutional Court held, the Labour Appeal Court had failed properly to appreciate the "totality of the circumstances" in determining whether the statement was used in a manner which is racist or derogatory. ${ }^{94}$ The Constitutional Court concluded

$85 \quad$ Bester CC para 34.

86 Kathree-Setiloane AJA with Jappie and Davis JJA concurring. The panel of judges was racially representative. See SA Equity Workers Association obo Bester $v$ Rustenburg Platinum Mine 201738 ILJ 1779 (LAC) (Bester LAC) para 19.

87 See Bester LAC para 19.

$88 \quad$ Bester LAC para 27; Bester CC para 22.

Bester CC para 48. Notably, the court does not substantiate this statement. On the contrary, the IRR 2017 https://www.politicsweb.co.za/documents/against-the-hatebill-the-irrs-full-submission refers to field studies which suggest otherwise: IRR Race Relations 2001; IRR Race Relations 2016; IRR Race Relations 2017. They show that very few South Africans, and even fewer black South Africans, consider racism to be a serious problem. StatsSA Survey.

$91 \quad$ Bester CC para 48. Whereas $12,2 \%$ of the white respondents indicated that they had experienced racial discrimination, the figure was 9,7\% for coloureds, 6,5\% for Indians/Asians and 5,8\% for black African respondents. IRR Race Relations 2017. 
that in context, the term had been used in a manner which was patently "racially loaded", derogatory and offensive. ${ }^{95}$

Both Bester CC and Khumalo involved racist slurs. In both cases the court was required to decide whether the utterances were derogatory and racist, and in both cases the courts concluded that the utterances were offensive and amounted to racism. But the two cases also differ in material respects: Bester CC concerned a racist utterance made in the employment context, whereas Khumalo's utterance had not been made while he was at work or in the performance of his duties. But should that make a difference in the approach that the court follows? The question will be answered by first looking at the policy considerations that informed the protections against hate speech and the making of racial slurs inside and outside of the workplace. Thereafter the differences between the protections provided inside and outside the workplace are considered.

\subsection{Policy considerations for the enactment of the protection inside and outside the workplace}

When interpreting the EEA and the PEPUDA, South Africa's international law obligations must be upheld. ${ }^{96}$ The national legislation must also be construed so as to underscore the constitutional values in section 1 of the Constitution, ${ }^{97}$ and to give effect to the purpose of the particular piece of legislation. ${ }^{98}$ In the light of the right to fair labour practices, ${ }^{99}$ labour forums must interpret the law equitably and apply it equally to all who are entitled to its protection. ${ }^{100}$

The preamble to the PEPUDA states its purpose:

... to facilitate the transition to a democratic society, united in its diversity, marked by human relations that are caring and compassionate, and guided by the principles of equality, fairness, equity, social progress, justice, human dignity and freedom.

$95 \quad$ Bester CC para 49.

96 Section 39 of the Constitution. See $s 3(d)$ of the EEA and $s 3(1)$ and $3(2)$ of the PEPUDA. Section 39(1)(c) of the Constitution determines that the court "may consider foreign law" when interpreting the rights contained in the Bill of Rights.

Section 1 of the Constitution determines: "The Republic of South Africa is one, sovereign, democratic state founded on the following values: (a) Human dignity, the achievement of equality and the advancement of human rights and freedoms. (b) Non-racialism and non-sexism. (c) Supremacy of the constitution and the rule of law."

98 Section 3 of the Labour Relations Act 66 of 1995 (the LRA).

$99 \quad$ Section 23 of the Constitution.

100 Geldenhuys 2016 SA Merc LJ 402. 
The PEPUDA prohibits the "advocacy of hatred based on race"101 and introduces measures to oust "unfair discrimination, hate speech and harassment" based on race. ${ }^{102}$ The PEPUDA also serves to provide remedies to the victims of these offences ${ }^{103}$ and to provide victims of hate speech with access to forums to which to refer their complaints. ${ }^{104}$

The Equality Court in Khumalo acknowledged that the PEPUDA aims to "overcome the fissures" in the South African society and to promote social cohesion between the different racial groups. ${ }^{105}$ Botha and Govindjee indicate, and we concur, that the PEPUDA was enacted with transformation of South African society in mind. ${ }^{106}$

The entire EEA was enacted to give effect to the right to equality in the Constitution. ${ }^{107}$ The Preamble to the EEA sets out this purpose. The EEA promotes equality in two ways: by ousting unfair discrimination in the workplace; 108 and by ensuring the implementation of affirmative action. ${ }^{109}$

Both the EEA and the PEPUDA propose substantive equality as the measure, and not formal equality. In drawing a distinction between formal and substantive equality, Currie and De Waal note that formal equality, i.e. where the same rights are extended to everyone, does not account for the real social and economic disparities between different population groups. ${ }^{110}$ In the light of the purpose of the Constitution to bridge the historical crevasse, identical treatment does not in the authors' view promote nonracialism. ${ }^{111}$ The prevailing social and economic inequality requires positive or affirmative action to advance the groups who were previously disadvantaged. ${ }^{112}$ Nonetheless, no sound basis exists in the wording of the

\footnotetext{
101 Section $2(b)(v)$ of the PEPUDA.

102 Section 2(c) of the PEPUDA.

103 Section 2(f) of the PEPUDA.

104 Botha and Govindjee 2017 PELJ 19.

105 Khumalo para 85.

106 Botha and Govindjee 2017 PELJ 4; see further Gutto Equality and NonDiscrimination in South Africa 17-95 for a discussion of the policy considerations that informed the enactment of the PEPUDA.

107 Section 9 of the Constitution.

108 Section 5 and 6 of the EEA.

109 Section 2 of the EEA; Khumalo para 85

110 Currie and De Waal Bill of Rights Handbook 213-214.

111 Currie and De Waal Bill of Rights Handbook 214. Also see National Coalition of Gay and Lesbian Equality v Minister of Justice 19991 SA 6 (CC); Minister of Finance $v$ Van Heerden 20046 SA 121 (CC) para 26.

112 Currie and De Waal Bill of Rights Handbook 241.
} 
legislative provisions under scrutiny to distinguish between the manner in which they are applied to different population groups.

\subsection{The protections on offer to victims depending on whether the racial utterance is made inside or outside the workplace}

The relationship between an employer and employee is one of trust and confidence. ${ }^{113}$ Employees who commit acts of racism in the workplace act contrary to the fiduciary duty that they owe their employers. ${ }^{114}$ The duty of good faith includes that workers must protect and further the employer's business interests. ${ }^{115}$ The common-law duty of trust and confidence further dictates that freedom of speech should be exercised within bounds in order to maintain harmonious working relationships. ${ }^{116}$ Racism constitutes misconduct which potentially falls within the realm of dismissible offences. ${ }^{117}$ Whether dismissal as a sanction for the making of a racist slur is apt depends on whether the relationship of trust is destroyed. ${ }^{118}$ Alternatively, an employer's disciplinary code may make reference to offences dealing with racism and stipulate when dismissal will follow. ${ }^{119}$ Botha expresses the opinion that an employer ought to dismiss an employee for racist utterances made outside the workplace on social media if the utterances have the potential of leading to disharmony in the workplace. ${ }^{120}$ This appears to be correct, because even if incidents of racism had not taken place in the workplace and/or had occurred while the employees were not on duty, the remedy offered by section 60 of the EEA to hold the employer liable could nevertheless be relied upon successfully. ${ }^{121}$ For instance, in Biggar and City of Johannesburg (Emergency Management Services) ${ }^{122}$ the court found that a sufficient link existed between the racism and employment despite the fact that the acts

\footnotetext{
113 Council for Scientific Industrial Research v Fijen 19962 SA 1 (SCA) para 17.

114 Botha 2018 THRHR 671.

115 Botha 2018 THRHR 675

116 Botha 2018 THRHR 675

117 Section 188 of the LRA determines that an employer may dismiss an employee for reasons related to his conduct, his capacity, or the employer's operational requirements.

118 Edcon Ltd v Pillemer 200930 ILJ 2642 (SCA) paras 17-20, 22; see further Botha 2018 THRHR 676.

119 Lebowa Platinum Mines Ltd v Hill 199819 ILJ 1112 (LAC) para 12.

120 Botha 2018 THRHR 680; see further Gordon v National Oilwell Varco 20179 BALR 935 (MEIBC) paras 56-58.

121 Campbell Scientific Africa (Pty) Ltd v Simmers 201637 ILJ 116 (LAC) (hereafter Simmers) involved sexual and not racial harassment, but it serves as an example of an instance where the court ruled that the employer could discipline the employee for harassment that did not take place in the work context.

122 Biggar v City of Johannesburg (Emergency Management Services) 201738 ILJ 1806 (LC).
} 
of racism did not occur at work. ${ }^{123}$ Therefore, the court was convinced that even though the racist utterance had been made outside the workplace, outside the ordinary working hours and not in the execution of duties, they had sullied the work environment. ${ }^{124}$ This approach was also followed in Dyonashe v Siyaya Skills Institute (Pty) Ltd ${ }^{125}$ and in Dolo v CCMA. ${ }^{126}$

But the duty of trust in employment cuts both ways. Employers are under a general duty to thwart discriminatory practices in the workplace. ${ }^{127}$ They must provide a working environment which is safe, and protect all employees from harm, whether physical or emotional. An employer can be held liable directly in the event of its failure to take steps to eradicate racial discrimination. ${ }^{128}$ The employer can also be held responsible for the racial statements made by employees or even other people in the workplace if certain requirements are met. ${ }^{129}$ Section 60 of the EEA determines that if an employee "while at work" contravenes a provision of the EEA, the conduct must be brought to the employer's attention immediately. ${ }^{130}$ If this is done, the employer must consult with all of the parties involved and take steps to address the conduct to prevent a recurrence. ${ }^{131}$ Moreover, the employer must institute disciplinary action against the perpetrator. ${ }^{132}$ Failure to take what is considered to be reasonable steps can lead to the liability of the employer for the conduct complained of. ${ }^{133}$ An employer can escape liability if it is able to prove that it had done all that was reasonably practicable to ensure that the employee would not again act in contravention of the EEA. ${ }^{134}$

However, the protection provided for in section 6 of the EEA against unfair discrimination in any employment policy or practice does not serve as

\footnotetext{
123 Also see Simmers para 25; Hoescht (Pty) Ltd v Chemical Workers Industrial Union 199314 ILJ 1449 (LAC) 1459B.

124 Biggar $v$ City of Johannesburg (Emergency Management Services) 201738 ILJ 1806 (LC).

125 Dyonashe v Siyaya Skills Institute (Pty) Ltd 20183 BALR 280 (CCMA).

126 Dolo v Commission for Conciliation, Mediation and Arbitration 201132 ILJ 905 (LC) para 19.

127 There is no specific statutory provision pertaining to the duty in the LRA or the EEA It is accepted at common law that an employer has a duty to ensure that the workplace is safe for all employees, physically and psychologically. Employers and employees also owe each other a duty of mutual trust and confidence, or mutual respect.

128 Media 24 Ltd v Grobler 20053 All SA 297 (SCA).

129 Section 60 of the EEA.

130 Section 60(1) of the EEA; Basson et al New Essential Labour Law Handbook 233.

131 Section $60(2)$ of the EEA.

132 Section 60(2) of the EEA; see further Botha 2018 THRHR 680.

133 Section $60(3)$ of the EEA.

134 Section $60(4)$ of the EEA.
} 
protection for a victim of hate speech or racist slurs in the workplace. ${ }^{135}$ In fact, the EEA does not specifically address the issue of making racist utterances, despite their recognised prevalence. ${ }^{136}$ The closest that the EEA comes is to recognise harassment as a subdivision of discrimination, which is prohibited. ${ }^{137}$

It is our view that an overlap exists between the protection offered inside the workplace and outside the workplace insofar as racist utterances which qualify as hate speech are concerned. Echoing our argument, in his article $^{138}$ Khumalo indicates that anybody who is discriminated against unfairly may in terms of the PEPUDA refer a [hate speech] ${ }^{139}$ complaint to the Equality Court and seek damages. ${ }^{140}$ Whether this view is correct is not clear from the legislation. The EEA does not explicitly provide a remedy to institute against perpetrators of hate speech, whereas the PEPUDA does.

The PEPUDA states that it (the PEPUDA) "does not apply to any person to whom and to the extent to which the EEA applies." 141 A conjunctive reading of this provision implies that the hate speech protection in the PEPUDA would not apply to "employees" to which the EEA applies. ${ }^{142}$ This appears to be confirmed by Strydom $v$ Chiloane. ${ }^{143}$

In Strydom the court considered whether a victim of a racist utterance made inside the workplace could simultaneously institute action against the

135 Compare s 6 of the EEA. None of the listed items in "employment policy and practice" in $\mathrm{s} 1$ of the EEA relates to racial utterances. Also see Kok 2009 SA Public Law 653. In Khumalo paras 17, 22 the court noted that the referral to the Roodepoort court had been framed on the basis of an alleged unfair discrimination as envisaged in $\mathrm{s}$ 7(a) of the PEPUDA, which is similar to $s 6$ of the EEA. The Equality Court noted that this was not the correct course of action when the facts suggested that hate speech had occurred, suggesting that a clear distinction must be drawn.

136 Basson et al New Essential Labour Law Handbook 240.

137 Section 6(3) of the EEA determines that "(1) No person may unfairly discriminate against a worker on the basis of: Race, gender, sex, pregnancy, marital status, family responsibility, ethnic or social origin, colour, sexual orientation, age, disability, religion, HIV status, conscience, belief, political opinion, culture, language and birth or on any other arbitrary ground."

138 Khumalo 2018 SA Merc LJ 382.

139 Our inclusion.

102 Khumalo 2018 SA Merc LJ 382.

141 Section 5(3) of the PEPUDA.

142 Section 4 of the EEA. Chapter II of the EEA, in which the provisions under scrutiny in this contribution resort is applicable (1) to all employers and employees.

143 Strydom v Chiloane 20082 SA 247 (T) (hereafter Strydom). In this case, a white mine captain, Strydom, in a meeting said to Chiloane "All the baboons are wanted on duty this weekend ... those baboons that will not be on duty this weekend will be dismissed ... . This baboon-government of yours will provide you with some jobs." 
employer ${ }^{144}$ and the perpetrator for alleged hate speech. ${ }^{145}$ In the Equality Court, the magistrate held that because the PEPUDA provides a remedy for hate speech, whereas the EEA does not, the Equality Court had jurisdiction. However, this judgment was overturned on appeal. The appeal court ${ }^{146}$ relying on Lebowa Platinum Mines Ltd $v$ Hill ${ }^{47}$ held that as soon as a racially discriminatory statement is uttered in the workplace, the conduct falls within the scope of section 6 of the EEA and the dispute should be resolved by the Labour Court. ${ }^{148}$ The court reasoned that the Labour Court could have dual jurisdiction, but that even so, section 49 of the EEA states that the Labour Court enjoys exclusive jurisdiction to decide on its jurisdiction. ${ }^{149}$ However, in the court's opinion, Chiloane was "entitled to ask why he cannot proceed with his action against the employer in the Labour Court and with his action against Strydom in the equality court", ${ }^{150}$ leaving the question hanging.

However, in City of Cape Town v Freddie ${ }^{151}$ the Labour Appeal Court noted to the contrary that using racist language against a person or a class of persons in the workplace also constitutes hate speech in terms of the Constitution and the PEPUDA. ${ }^{152}$ This statement would be incorrect if conduct committed in employment fell beyond the scope of the application of the PEPUDA's hate speech protection. Currie and De Waal understand section 5(3) of the PEPUDA to mean: the same complaint cannot be referred in terms of both the EEA and the PEPUDA. If the EEA applies, the operation of the PEPUDA is excluded. ${ }^{153}$ Kok argues that it would be anomalous to include hate speech in the EEA, because of the fact that a defence of "fair" discrimination can be raised in terms of the EEA, whereas the PEPUDA does not provide for fairness as a defence. ${ }^{154}$ That is why the EEA does not provide a remedy against hate speech. He contends, in our opinion correctly, that the fact that hate speech is provided for in the

144 In terms of 50 of the EEA an employer may be held liable for not taking reasonable steps to address the concerns that had been brought to its attention concerning racist utterances.

145 Strydom paras 15,16

146 Strydom para 10.

147 Lebowa Platinum Mines Ltd v Hill 199819 ILJ 1112 (LAC).

148 But, as explained, hate speech does not fit comfortably under the protection of $\mathrm{s} 6$ of the EEA.

149 In para 15 of the Strydom judgment the court expressed the opinion that Chiloane could institute a claim in an ordinary court on the ground of crimen injuria; also see Kok 2009 SA Public Law 653.

150 Strydom para 15; Kok 2009 SA Public Law 653.

151 City of Cape Town v Freddie 201637 ILJ 1364 (LAC) paras 54-56.

152 Section 16(2) (c) of the Constitution; s 10(1) of the PEPUDA; City of Cape Town v Freddie 201637 ILJ 1364 (LAC) para 55.

153 Currie and De Waal Bill of Rights Handbook 245 fn. 182.

154 Kok 2009 SA Public Law 654. 
PEPUDA and not also in the EEA shows the legislator's intention that all hate speech matters should be handled by the equality court, whether the utterance was made inside or outside the workplace. ${ }^{155}$ Not allowing employees to refer cases based on hate speech would be contrary to the right in section 34 of the Constitution to refer a dispute to a fair public hearing by an impartial court. ${ }^{156}$

Whether the racist utterance is made in the workplace in the course of the execution of work is becoming less important. In the light of the manner in which the courts and employers have responded to acts of racism, harassment and hate speech, the significance of this jurisdictional fact has diminished. It is difficult to support an argument that there can be different starting points in relation to the enquiry of whether a racist slur should be sanctionable, dependent on whether it was made inside or outside the workplace.

\section{The public policy and historical context}

\subsection{Introduction}

Currie and De Waal ${ }^{157}$ posit that the history and political context in the country play an incremental role in the manner in which the Bill of Rights, and accordingly also the legislation enacted to give effect to its values, are interpreted. They reason that the interpretation that is afforded should reflect "a ringing and decisive break with the past". ${ }^{158}$ This means being careful not to repeat mistakes that were made in the past. ${ }^{159}$ In construing section 9 of the Constitution, the history that necessitated adopting the fundamental right is one of the factors that the court must take into consideration. ${ }^{160}$ Botha and Govindjee argue that the "historical patterns of discrimination against a group and social political circumstances" are among the important contextual factors that must be considered in determining whether a link exists between a racist utterance and the potential to harm in a hate speech case. ${ }^{161}$ Does the current social context in South Africa and the history of oppression and the remaining inequalities dictate that the starting point as

\footnotetext{
$155 \quad$ Kok 2009 SA Public Law 654.

156 Bekink Principles of South African Constitutional Law 491.

157 Currie and De Waal Bill of Rights Handbook 141.

158 As held by Mahomed J in S v Mhlungu 19953 SA 391 (CC) para 8.

159 Currie and De Waal Bill of Rights Handbook 141.

160 Currie and De Waal Bill of Rights Handbook 142 fn. 37; see further Brink v Kitshoff 19964 SA 197 (CC) para 40; Harksen v Lane 19981 SA 300 (CC) para 52; City Council of Pretoria $v$ Walker 19982 SA 363 (CC) paras 45-48; De Lange $v$ Smuts 19983 SA 785 (CC). Also see Khumalo 2018 SA Merc LJ 377-394. 
suggested in Bester CC should be applied in all cases in which racist utterances are made? If not, what role, if any, should this factor play ${ }^{162}$ In the University of Oxford "Comparative Hate Speech Law: Memorandum"163 the question of what role historical and socio-political considerations should play in balancing the various constitutional rights and in ascertaining whether an utterance constitutes hate speech is also considered. ${ }^{164}$ The authors refer to the decision of the Victorian Court of Appeal in Australia in Catch the Fire Ministries Inc $v$ Islamic Council of Victoria, ${ }^{165}$ in which it was held:

\begin{abstract}
It is trite ... that the social and historical context in which words are spoken ... alters from time to time. Changes in social context mean that words directed against members of a particular racial or religious group could be found to have the relevant inciting effect at one time, which they would not have at another time. ${ }^{166}$
\end{abstract}

This suggests that it would be wrong to set any kind of precedent, as has been done in Bester CC, as the prevailing norms of society or the public policy or good morals may change. But was the court in Bester CC correct in the light of the current views in practice of employers, the courts and the SAHRC in relation to the making of racist slurs? This is considered with reference to recent incidents described below.

\title{
4.1.1 The view of employers
}

Employers appear to take alleged acts of racism in the workplace very seriously. Considering the fact that they may be held accountable if they are found in want of taking reasonable steps to address it inside and outside of the workplace, this makes sense. But again there appear to be some discrepancies along racial lines. For instance, the utterance in Khumalo was not made in the workplace. ${ }^{167}$ Nevertheless, because the utterances were made on social media and disseminated widely in the public domain, Khumalo's employer issued a public announcement indicating that disciplinary steps would be taken against him. Whereas Khumalo was

162 This question was also posed in the Oxford Pro Bono Publico 2012 https://www.law.ox.ac.uk/sites/files/oxlaw/1._comparative_hate_speech_-_Irc.pdf 3.

163 Oxford Pro Bono Publico 2012 https://www.law.ox.ac.uk/sites/files/oxlaw/1. comparative_hate_speech_-_Irc.pdf.

164 Oxford Pro Bono Publico 2012 https://www.law.ox.ac.uk/sites/files/oxlaw/1. comparative_hate_speech_-_Irc.pdf 1 .

165 Catch the Fire Ministries Inc $v$ Islamic Council of Victoria 2006 VSCA 248; 200615 VR 207, 249 [132] (hereafter Catch the Fire Ministries) 254-255.

$166 \quad$ Catch the Fire Ministries para 158.

167 Bester CC was a labour dispute concerning the fairness of Bester's dismissal for insubordination and for making a racist statement, whereas Khumalo was framed as a hate speech claim under the PEPUDA. 
initially suspended for his misconduct, he was allowed back to work on a final written warning. ${ }^{168}$

Morota, a law lecturer at the University of South Africa and an advocate, had posted on Facebook: "I hate white people and must go back wherever they come from or alternatively to hell [sic]". Later he posted:

Educated blacks have an attitude of contempt toward their own black people because the education system taught them to admire all light skin races in the world and despise the African.

In response to a question of whether he was serious, Morota replied:

i don't entertain white cockroach like yourself ... i don't understand why you interfere in my black business ... $\mathrm{F}^{*} \mathrm{ck}$ you pink white murderer ... Enjoy the blood wealth of our people, your time to pay with your white skin is emmenent $\left[\right.$ sic]. ${ }^{169}$

Despite several complaints being lodged, no disciplinary action was taken against Morota. He was apparently warned that his conduct was unacceptable. ${ }^{170}$

In another case of alleged hate speech, Adam Catzavelos' family repudiated the utterance that Adam Catzavelos had made on a video while he was on holiday in Greece. ${ }^{171} \mathrm{~A}$ number of companies had cancelled their relationship with Catzavelos' family business. In a public statement the Catzavelos family indicated that Catzavelos had been dismissed with immediate effect from the family business of which he owned a third share. ${ }^{172}$

\footnotetext{
$168 \quad$ Khumalo para 35.

169 Burger 2016 https://www.netwerk24.com/Nuus/Politiek/ernstig-gewaarsku-oor-witkakkerlakke-20161022; Burger 2016 https://nuus.info/dosent-na-wit-kokkerotte-nogongestraf/; Natasha Stop White Genocide in SA 2016 https://stopwhitegenocideinsareports.blogspot.com/2016/06/black-unisa-lecturerwho-called-white.html.

170 Burger 2016 https://www.netwerk24.com/Nuus/Politiek/ernstig-gewaarsku-oor-witkakkerlakke-20161022; Burger 2016 https://nuus.info/dosent-na-wit-kokkerotte-nogongestraf/; Natasha Stop White Genocide in SA 2016 https://stopwhitegenocideinsareports.blogspot.com/2016/06/black-unisa-lecturerwho-called-white.html.

171 He stated: "Not a $f^{* * *}$ en [k-word] in sight. Heaven on earth".

172 Lindeque 2019 https://ewn.co.za/2018/08/22/adam-catzavelos-fired-from-familybusiness-after-racist-video; see further Mabuza and Gous 2019 https://www.timeslive.co.za/news/south-africa/2018-08-22-family-sorry-for-hurtcaused-by-catzavelos-as-death-threats-are-made/; Lawrence Beeld 10.
} 
Multichoice also took serious steps against Steve Hofmeyr for making "racially motivated statements" on social media. ${ }^{173}$ MultiChoice vowed to remove all content in which Hofmeyr appeared from its platforms and requested that a music video for a song entitled "Die Land" (The Land) that he sang with other singers, which had been nominated for a music award, be withdrawn. MultiChoice indicated that they could not be associated with Hofmeyr. ${ }^{174}$ More recently, MultiChoice made a similar decision when it decided not to air the second season of a reality show featuring Mike Bolhuis, a private detective, although production had already been completed. ${ }^{175}$

During 2018 two elderly white men were assaulted. One died, the other sustained serious injuries. After a photo of one of the victims was posted on social media, Major Mageti Vincent Mohlala, while in the employ of the South African National Defence Force (SANDF), commented on a social media platform that the attacker

[s]hould actually have poked out the victim's eyes and tongue so that the last people he would ever see, were the killers and he could go to his grave with the nightmare.

Mohlala added:

... apartheid is in him. All of these old white people think we are stupid when they say they were opposed to apartheid. We will not forget what they have done. Now it is the white people's turn. ${ }^{176}$

Mohlala initially only received a warning, contrary to section 105(1) of the National Defence Act 42 of 2002, which requires that the SANDF must fulfil a unifying role in South Africa. Ultimately, Mohlala was dismissed by the SANDF only after AfriForum requested written reasons for the SANDF's inaction. ${ }^{177}$

173 Kaunda 2019 https://citizen.co.za/news/south-africa/social-media/2137223/afriforum-wants-multichoice-to-pull-a-steve-hofmeyr-on-ntsiki-mazwai/.

174 Anon 2019 https://www.enca.com/life/multichoice-bans-all-of-steve-hofmeyrsmusic. Also see Ghoema Musiek Trust 2019 http://ghoema.co.za/.

175 Bolhuis's utterance in a WhatsApp voice note to a student who claimed that he was being blackmailed by an unknown woman indicated that the blackmailer was not a woman but "a $n^{*} \mathrm{gg}^{*} \mathrm{r}$, it's a pitch-black houtkop". Okoye 2019 https://citizen.co.za/news/south-africa/investigation/2165938/bolhuis-mum-asshow-cancelled-over-alleged-racial-slurs/.

176 SAPeople 2018 https://www.sapeople.com/2018/03/29/reasons-must-be-providedfor-not-charging-major-over-racist-statements/.

177 AfriForum $2018 \mathrm{https}: / /$ www.afriforum.co.za/en/afriforum-welcomes-dismissalmajor-mohlala-hate-speech/. 


\subsubsection{The view of the SAHRC}

The SAHRC is established in terms of Chapter 9 of the Constitution to give practical effect to the rights contained in the Constitution. ${ }^{178}$ The SAHRC must promote and protect human rights in terms of section 184 of the Constitution and its own legislation, the South African Human Rights Commission Act 40 of 2013. The functions of the SAHRC include to "investigate and report on the observance of human rights"179 and to "take steps in order to secure appropriate redress" in the event that it is found that a human right has been violated. ${ }^{180}$ However, the SAHRC has been criticised for the manner in which it deals with cases of alleged racism and hate speech. ${ }^{181}$ The SAHRC must perform this function impartially, "without fear, favour or prejudice."182 It must endorse the values in the International Convention on the Elimination of All Forms of Racial Discrimination, 1969 (the ICERD). ${ }^{183}$ The Committee for Elimination of Racial Discrimination's General Recommendation 35 paragraph 15 indicates what factors should be considered when deciding whether a racist utterance is sanctionable. It contains no provisos to the guidelines regarding hate speech as laid down in the ICERD which justify not acting against all cases of alleged hate speech or racist utterances.

The SAHRC took steps against Sparrow on its own initiative. The SAHRC also launched investigations into Chris Hart (an economist working for Standard Bank at the time), ${ }^{184}$ Mabel Jansen (a former judge) ${ }^{185}$ and Justin

\footnotetext{
178 Bekink Principles of South African Constitutional Law 583-584.

179 Section 184(2)(a) of the Constitution. For more information regarding the duties of the SAHRC under national legislation, see Geldenhuys 2019 TSAR 647-649.

180 Section 184(2)(b) of the Constitution; Bekink Principles of South African Constitutional Law 584.

181 Murray 2006 PELJ 126; Van Niekerk 2019 https://www.netwerk24.com/ Stemme/Menings/hier-maak-die-mrk-droog-20190415; $\quad$ Bosman 2019 https://maroelamedia.co.za/debat/meningsvormers/menseregtekommissie-skeernie-almal-oor-dieselfde-kam/.

182 Section 4(1)(a) of the South African Human Rights Commission Act 40 of 2013.

183 Section 13(b)(vi) and (vii) of the South African Human Rights Commission Act 40 of 2013. South Africa has ratified the International Convention on the Elimination of All Forms of Racial Discrimination (1965) (ICERD). See UNHRC 2019 https://indicators.ohchr.org/.

184 Hart had posted on Twitter: "More than 25 years after Apartheid ended, the victims are increasing along with a sense of entitlement and hatred towards minorities..." He apologised, but his employer threatened to take disciplinary action against him, and he resigned. Mawson 2016 https://www.iol.co.za/business-report/companies/ who-is-chris-hart-1966769; Agency 2016 https://mg.co.za/article/2016-03-15standard-banks-chris-hart-resigns.

185 The former judge had made several statements to a journalist regarding black people's alleged cultural inclination to rape.
} 
van Vuuren. ${ }^{186}$ It is unclear why the SAHRC chose to act on own initiative in these instances and not in others. ${ }^{187}$

In its findings regarding Malema's "white slaughter utterance" 188 the SAHRC indicated that the statement had been made in the context of land and that it is true that white South Africans occupy the land of black people and still enjoy significant economic power. ${ }^{189}$ Therefore, the utterance was a permissible expression of "anger and pain through robust speech"190 absent an imminent threat of violence. ${ }^{191}$ Whereas Malema's statement was considered a justifiable "political statement"192 Helen Zille, who was the former Western Cape Premier of the Democratic Alliance at the time of making the utterance, was apparently not afforded the same leniency. She had posted: "For those claiming that the legacy of colonialism was only negative, think of our independent judiciary, transport infrastructure, piped water etc." In Zille's case, the stance was taken that politicians and highly placed individuals should not be permitted to make statements that have the potential to cause a racial divide. This matter is currently being investigated further by the Public Protector, even though Zille is no longer in office. ${ }^{193}$

Another example concerned Zindzi Mandela-Hlongwane, Winnie Madakizela Mandela and Nelson Mandela's late daughter. On her Twitter account she had described white South Africans as "trembling white cowards", "Thieving Rapist descendants of Van Riebeck (sic)" and "shivering land thieves". The spokesperson of the EFF, Mbuyiseni Ndlozi at the time, stated that the EFF supported Mandela-Hlongwane's tweets and her views. ${ }^{194}$ AfriForum immediately requested the Minister of International Relations and Cooperation, Dr Naledi Pandor, to recall and dismiss

186 Like Sparrow he had criticised black holiday makers on the Durban beaches on his Facebook page. See Anon 2016 https://www.enca.com/south-africa/penny-sparrowfeels-twitter-wrath.

187 Brink and Mulder $2017 \mathrm{https}: / /$ solidariteit.co.za/wp-content/uploads/2017/10/ Racism-hate-speech-and-double-standards-by-no-means-a-mere-matter-ofbla....pdf.

188 SAHRC Findings - refer to the Introduction.

189 SAHRC Findings para 16.

190 SAHRC Findings para 16.2; Hotz v University of Cape Town 20172 SA 485 (SCA) para 67.

191 SAHRC Findings para 17.

192 Jana 2019 https://www.politicsweb.co.za/documents/malemas-white-slaughterremarks-the-sahrcs-finding.

193 Maughan 2019 https://www.businesslive.co.za/bd/politics/2019-08-07-helen-zilleand-busisiwe-mkhwebane-to-square-off-over-colonialism-tweets/.

194 Maroela Redaksie 2019 https://maroelamedia.co.za/nuus/sa-nuus/eff-beaamzindzi-mandela-se-uitlatings/. 
Mandela-Hlongwane as the South African Ambassador. AfriForum argued that an ambassador is under a legal duty to act for all residents of the country represented, while promoting their interests without favour or prejudice. ${ }^{195}$ Minister Pandor confirmed that the Department has a social media policy that all ambassadors must adhere to and that MandelaHlongwane's conduct would be investigated. ${ }^{196}$ Even though her contract of appointment as ambassador was due to expire, it was extended for another six months, despite the controversial tweets. AfriForum lodged an official complaint at the SAHRC. ${ }^{197}$ However, there were commentators who felt that her comment was justified because of her personal circumstances. Among other negative impacts that she had suffered during apartheid, her father, the late Nelson Mandela, had been imprisoned for 27 years. Consequently, she was deprived of the opportunity to grow up with him. ${ }^{198}$ On its official website the SAHRC states that "the history of Zindzi Mandela and her family needs to be taken into account during any investigation into her tweets on land reform."199

\subsubsection{The view of the courts}

Besides the suggestion made in Bester $\mathrm{CC}$ regarding what the starting point should be in assessing whether or not a statement is racist and derogatory, the court often considers the historical context as part of the assessment into whether the contents of a statement or the "words" used in the utterance are derogatory and racist.

The court is patent in regarding its denunciation of using the k-word inside or outside the workplace. The k-word is notorious for often attracting the harshest penalty in the employment context: dismissal. ${ }^{200}$ In South African Breweries (Pty) Ltd v Hansen ${ }^{201}$ the court ruled that it is unnecessary for the employer to prove that the utterance containing the k-word is objectively derogatory. ${ }^{202}$ The k-word is considered to be so blatantly derogatory that

\footnotetext{
195 AfriForum 2019 https://allafrica.com/stories/201906170365.html.

196 Zibi 2019 https://www.msn.com/en-za/news/politicsvideo/dirco-investigating-zindzimandela-tweets/ar-AAD3xvE.

197 Cornelissen 2019 https://maroelamedia.co.za/nuus/sa-nuus/klagte-teen-zindzimandela-by-menseregtekommissie-ingedien/.

198 Anon 2019 https://www.zimeye.net/2019/06/18/latest-on-zindzi-mandela-landthieves-tweet/\#; Staff Reporter 2019 https://www.iol.co.za/news/politics/ zindzimandela-divides-twitter-with-ourland-tweets-26346019.

199 SAHRC 2019 https://sahrc.org.za/index.php/sahrc-media/news/item/2030-sahrcwill-consider-probe-into-zindzi-mandela-tweets.

200 City of Cape Town v Freddie 201637 ILJ 1364 (LAC).

201 South African Breweries (Pty) Ltd v Hansen 201738 ILJ 1766 (LAC).

202 SAEWU v Rustenburg Platinum Mines (LAC) case number JA 45/2016 of 3 May 2017.
} 
its nature is taken to be established. ${ }^{203}$ In South African Revenue Service and Commission for Conciliation, Mediation and Arbitration, ${ }^{204}$ the Constitutional Court agreed that the k-word is "the embodiment of racial supremacy and hatred."205 To allow its use in the workplace would perpetuate the racism that black South Africans have had to suffer during apartheid. Not to take a serious stance would also point to the fact that "very little attitudinal or mind-set change has taken place since the dawn of our democracy."206

A black person can also be guilty of injuring the feelings of another black person by using the k-word. Peter-Paul Ngwenya was charged for allegedly using the k-word in a text message addressed to his previous business partner and friend, Fani Titi. ${ }^{207}$ Ngwenya's legal representative had argued that the k-word is offensive only when used by whites ${ }^{208}$ and that the word "has a different meaning when used by black people among themselves."209 Judgment was handed down on 22 August $2019^{210}$ by the same magistrate who had sentenced Momberg to jail for three years. ${ }^{211}$ Ngwenya was found guilty of crimen injuria. He was sentenced on 7 May 2020 with a fine of R24 000 or twelve months in prison wholly suspended for three years, on condition that he is not found guilty of crimen injuria again during that same period. ${ }^{212}$ The magistrate held that using the k-word is always hate speech,

203 South African Revenue Service $v$ Commission for Conciliation, Mediation and Arbitration 201738 ILJ 97 (CC) paras 4 and 53; Thembani v Swanepoel 20173 SA 70 (ECM); Crown Chickens (Pty) Ltd t/a Rocklands Poultry v Kapp 20026 BLLR 493 (LAC) para 35 in which the history, meaning and implication is elaborated on.

204 South African Revenue Service $v$ Commission for Conciliation, Mediation and Arbitration 201738 ILJ 97 (CC) (hereafter SARS).

205 SARS para 9.

206 SARS para 7.

207 He referred to Titi as a "Qwaqwa [k-word]" and a "Bantustan boss". Ngwenya intended to send the text message containing the utterances to someone else but sent it to Titi by mistake.

208 Jordaan 2019 https://www.sowetanlive.co.za/news/south-africa/2019-05-23-k-wordcan-be-offensive-only-when-used-by-whites-says-ngwenyas-lawyer/.

209 Nkosi 2019 https://www.iol.co.za/the-star/news/peter-paul-ngwenyas-defence-ofblack-on-black-slur-disingenuous-court-hears-23830007.

210 Jordaan 2019 https://www.timeslive.co.za/news/south-africa/2019-07-16-judgmentin-businessmens-k-word-spat-to-be-delivered-in-august/.

211 Mahamba 2019 https://www.iol.co.za/the-star/news/why-would-an-ex-robbenislander-call-another-black-person-a-kr-14628934; see further Jordaan 2019 https://select.timeslive.co.za/news/2019-08-23-final-word-on-the-k-word-its-not-okwhether-youre-black-or-white/.

212 Cilliers 2020 https://citizen.co.za/news/south-africa/courts/2237551/peter-paulngwenya-fined-r24k-suspended-for-use-of-k-word-on-investecs-ceo/. Unfortunately, the case is not reported. We are therefore reliant on news reports for information regarding the outcome of the case. 
even if the perpetrator is black. ${ }^{213}$ The magistrate confirmed that when used by one black individual in addressing another the k-word is not part of the culture of black South Africans. ${ }^{214}$

When used to refer to white South Africans, "boer" is also recognised as a derogatory epithet. ${ }^{215}$ Recently a bargaining council commissioner in Makhanya v St Gobain ${ }^{216}$ confirmed that "boer" carries similar derogatory connotations to the k-word. ${ }^{217}$ Comparing people to "cockroaches"218 is also very serious. It is reminiscent of the language used in Rwanda before the Tutsi genocide. In fact, the Rwandan who made this utterance was given a life sentence, as it is believed that making this utterance had spurred on the genocide. ${ }^{219}$

Whether it is racist to accuse someone of being a racist without reasonable justification is not as clear. In SA Commercial Catering and Allied Workers Union obo Sikhundla and Radisson BluHotel Waterfront ${ }^{220}$ it was remarked by the CCMA commissioner that making false accusations of racism "casts a bleak shadow over efforts to heal the rifts between people of various races." He concluded that it did amount to racism. ${ }^{221}$ Conversely, in Vodacom (Pty) Ltd $v$ Byrne 222 (Vodacom), where the perpetrator had allegedly called his manager a "bloody racist who hates all blacks"223 without cause, ${ }^{224}$ he was not found guilty of having made a racist utterance. The CCMA commissioner noted that calling someone a racist is just stating what you believe. For someone to be a racist, this must be substantiated by facts. $^{225}$ On review, Van Niekerk $J$ declined to answer the question of

213 Khumalo agrees that uttering the k-word is "inherently racist irrespective of the context". See Khumalo 2018 SA Merc LJ 392.

214 Khumalo 2018 SA Merc LJ 392.

215 Freedom Front $v$ South African Human Rights Commission 200311 BCLR 1283 (SAHRC) 1290. In contrast, see Duncanmec (Pty) Limited v Gaylard 20186 SA 335 (CC) para 37.

216 Makhanya $v$ St Gobain 20197 BALR 720 (NBCCI).

217 Pienaar 2019 https://www.golegal.co.za/derogatory-language-workplace/.

218 Morota had used this epithet in his posting on Facebook. See the Introduction and the discussion under 4.1.1.

219 O'Grady 2015 https://foreignpolicy.com/2016/04/15/rwandan-who-called-tutsiscockroaches-in-1992-gets-life-sentence/.

220 SA Commercial Catering and Allied Workers Union obo Sikhundla and Radisson BluHotel Waterfront 201031 ILJ 1500 (CCMA); Khumalo 2018 SA Merc LJ 385-386.

221 SA Commercial Catering and Allied Workers Union obo Sikhundla and Radisson BluHotel Waterfront 201031 ILJ 1500 (CCMA) para 44.

222 Vodacom v Byrne 201233 ILJ 2705 (LC) (hereafter Vodacom).

223 Vodacom para 1.

$224 \quad$ Vodacom para 2.

225 Vodacom paras $3,4$. 
whether calling someone a racist constitutes racism. ${ }^{226} \mathrm{He}$ observed that it is the opinion of some that it is impossible for a black person to be guilty of racism. ${ }^{227}$ But in City of Cape Town v Freddie, ${ }^{228}$ Freddie had called Robson a racist for no reason. ${ }^{229}$ Robson was not white but a coloured. The court concluded that this "racial insult" was unacceptable for any employee to use against any other employee in the workplace, irrespective of race.

Using the word "baboon" in South Africa to refer to a black person is taboo owing to the South African historical political context. ${ }^{230}$ It is generally accepted that to call a black South African a "baboon" is demeaning. ${ }^{231}$ In Strydom $v$ Chiloane ${ }^{232}$ and Mangope $v$ AsmaR33 the court held that using the term suggests that someone has below normal intelligence. The court in Herselman $v$ Geleba ${ }^{234}$ (Herselman) noted that this is the meaning that the reasonable black South African would attach to "baboon" and that this meaning has the potential of infringing on the right to dignity. ${ }^{235}$

In Herselman, Dawood J considered whether the utterance "Moenie soos 'n bobbejaan wees nie, jy is besig om die gebou te beskadig..." ("Don't be like a baboon, you are damaging the building...") constituted hate speech. ${ }^{236}$ Herselman contended that he intended to convey that what Geleba was doing was stupid. ${ }^{237}$ The court a quo ${ }^{238}$ had held that an utterance should be interrogated on the basis of its social context. ${ }^{239}$ Notwithstanding, the court rejected Herselman's explanations of how the word "bobbejaan" is conventionally used in the Afrikaans language, that is to indicate that someone is "being silly", as in the English expression "monkey business". 240

Before the Qwelane SCA judgment was handed down, the Equality Court (per Mojapelo DJP) in Nelson Mandela Foundation Trust and SAHRC $v$

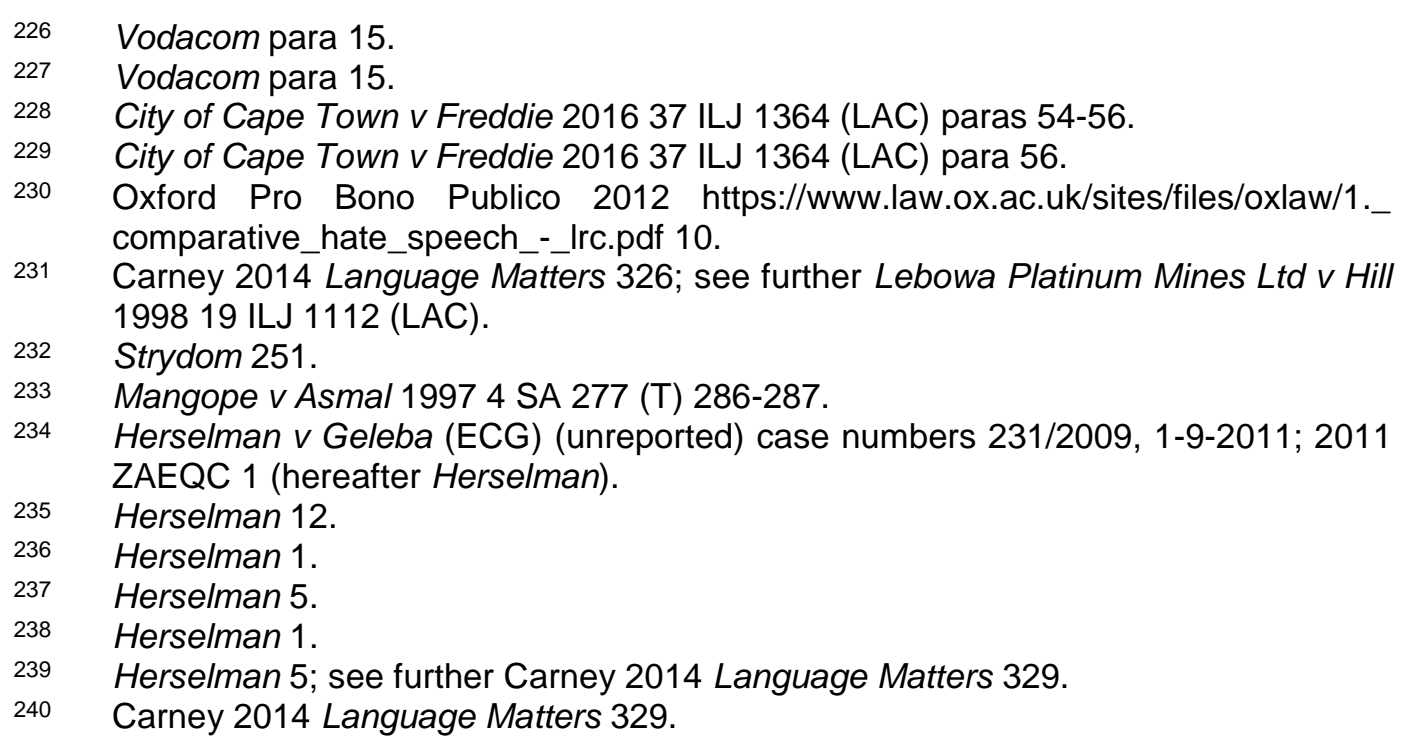


AfriForum ${ }^{241}$ had also considered the history of the old South African flag to decide whether gratuitously displaying it should be permissible. ${ }^{242}$ The court noted that the old flag had been introduced in 1928 by white leaders. The court considered the parties' contentions of what the flag meant to each of them. ${ }^{243}$ The FAK had put forward that they saw the flag as a cultural symbol of reconciliation between the boers and the English, ${ }^{244}$ but the court did not consider this as a reason to override the interests of the black majority. ${ }^{245}$ The dominant meaning assigned to the old flag in South Africa was that it was an endorsement of apartheid. ${ }^{246}$ This was also the dominant meaning assigned to the old flag internationally. 247 Therefore, Mojapelo DJP concluded that the old flag was a symbol of racial segregation and oppression of black South Africans, and that its gratuitous display constituted hate speech, ${ }^{248}$ harassment, ${ }^{249}$ and unfair discrimination ${ }^{250}$ under the PEPUDA. ${ }^{251}$ The court considered the historical context in relation to whether the display of the flag should fall within the scope of section 10(1) as it was originally enacted. However, the court paid little regard to the specific context in which the flag had been used by the perpetrators (white South Africans). The flag had been used in a peaceful march by white farmers in opposition to the staggering number of farm murders in South Africa. ${ }^{252}$

Simply relying on the meanings attributed to expressions in previous case law in this manner is contradictory to the approach that the context or circumstances of making of the utterance must be taken into consideration holistically. To employ an approach where a presumption of racism is

\footnotetext{
241 Nelson Mandela Foundation Trust v AfriForum 20196 SA 327 (GJ) (hereafter Mandela Foundation). For a discussion of the case, see Herd 2019 PSLR.

242 Mandela Foundation paras 31-54.

243 Mandela Foundation paras 63-72.

244 Mandela Foundation paras 62, 79

245 Mandela Foundation para 73.

246 Mandela Foundation para 75

247 Mandela Foundation paras 82-91.

248 Section 10(1) of the PEPUDA.

249 Section 11 of the PEPUDA.

250 Section 7 of the PEPUDA.

251 Mandela Foundation paras 200, 205. The court ruled that it was still permissible to display the old flag in cases where it would serve a journalistic, academic or artistic purpose in the public interest (para 56). However, after the Mandela Foundation judgment, in Qwelane SCA, s 10(1) of the PEPUDA was declared unconstitutional. On the basis of this finding, AfriForum was recently granted leave to appeal against the Mandela Foundation judgment. See Venter 2020 https://www.netwerk24.com /Nuus/Hof/afriforum-kry-verlof-tot-appel-oor-ou-landsvlag-20200508.

252 Mandela Foundation para 4. With reference to the recent spate of farm murders, the SAHRC in Khumalo had argued that his utterance incited genocide and propagated hatred against white South Africans.
} 
applied inconsistently and ostensibly along racial lines to instances where racial statements were made inside as opposed to outside of the workplace is disputatious. Moreover, an argument that an expression is context-bound for one population group, but not also for another based on historical events does not ring true.

\section{Observations and conclusion}

Rosenfeld opines that a "[r]eaction by the oppressed even if tinged with hatred should $\ldots$ be somewhat more tolerated than hate messages by members of traditionally oppressor groups". ${ }^{253}$ The prevailing view appears to be similar: if someone belonging to the conventional oppressor population group (in South Africa, whites) makes an utterance it will be considered to be racist and derogatory more readily. ${ }^{254}$ Moreover, if the perpetrator falls within a population group that was previously marginalised, the court or SAHRC should be more lenient. ${ }^{255}$ The findings in Bester CC suggest that the same applies in the employment context. But, if the utterance is made by a black person to another black person, even if it contains words that bears a historically negative connotation, it is unlikely to be considered a breach of the prohibition against hate speech. ${ }^{256}$

In Bester CC the Constitutional Court expressed its fears that to adopt a mitigating approach by focussing on technicalities instead of addressing the racism would have the effect of openly normalising racism in South Africa again. ${ }^{257}$ Consequently, the court vowed to adopt a "firm and unapologetic" approach to racism. ${ }^{258}$ The aim is to achieve non-racialism in the South African society. For this ideal to be realised, the court noted, no racial slurs should be permitted. ${ }^{259}$ However, the Constitutional Court suggests that racism by whites against blacks is the prevailing norm and that this dictates

\footnotetext{
253 Rosenfeld Hate Speech in Constitutional Jurisprudence 5.

254 See Hagan v Trustees of the Toowoomba Sports Grounds Trust 2000 FCA 1615 para 31. A white person called an indigenous person a "nigger". This case was framed as a racial discrimination case. Also see Oxford Pro Bono Publico 2012 https://www.law.ox.ac.uk/sites/files/oxlaw/1._comparative_hate_speech_-_Irc.pdf 14.

255 Rosenfeld Hate Speech in Constitutional Jurisprudence 5; see further Oxford Pro Bono Publico 2012 https://www.law.ox.ac.uk/sites/files/oxlaw/1._comparative_ hate_speech_-_Irc.pdf 7.

256 See, for instance, Hagan v Trustees of the Toowoomba Sports Grounds Trust 2000 FCA 1615 para 7.

257 Bester CC paras 10-11.

258 Bester CC paras 7-14.

259 Bester CC para 53
} 
that a different starting point be used when the perpetrator is white. This premise is not corroborated by the most recent statistics. ${ }^{260}$

We agree that the historical context of the racial group should be part of the assessment concerning the effect of the utterance from the point of view of the victim. However, the race of the perpetrator should not be the starting point in determining whether or not the statement is harmful to the victim as suggested in Bester CC. In Khumalo too it would have been incorrect to consider Khumalo's race on the general premise that he belonged to a population group that had been previously disadvantaged during apartheid as the point of departure in determining whether he was guilty of hate speech. ${ }^{261}$ This leaves several questions unanswered. What if the utterer and/or the victims are young and cannot be said to have suffered the ills of apartheid? Would this approach be correct if the utterer was a young black person from a very wealthy and privileged family and the victim was a young poor, white person living on the street?

In recognition of the duty to uphold international obligations in applying the legislation adopted under the Constitution, the interests of all race groups in South Africa ought to be considered. ${ }^{262}$ For the SAHRC ostensibly to pursue certain cases against general members of the public with gusto, while letting opinion leaders and public figures off the hook because of the historical context, contradicts the right to equality and dignity. Moreover, to deny a population group protection against hate speech and consequently the right to access to justice based on race does not pass constitutional muster. ${ }^{263}$

In Khumalo the Equality Court held, and we agree, that it would defeat the purpose of the PEPUDA to treat one population group differently from another in its application. The fissures in South African society cannot be bridged as envisaged by the Constitution if on the one hand black South Africans can debate the issue of racial inequality while on the other hand white South Africans are "disciplined to remain silent". In short, not acknowledging and acting against hate speech and racist slurs against whites in the same manner as blacks does nothing to promote social cohesion. ${ }^{264}$ The court was also correct in our view to recognise the historical context as a factor forming part of the surrounding circumstances

\footnotetext{
260 See the discussion under 3.1 and in particular fn. 90 and 92 above.

$261 \quad$ Khumalo para 48.

262 See the discussion under 4.1.2.

263 Section 34 of the Constitution. See the discussion under 2 and 3.3.

264 Khumalo para 102.
} 
which should be considered by the court in deciding on an appropriate remedy. ${ }^{265}$

However, to include the perpetrator's history, race and background in the list of contextual factors and as the starting point in deciding on the issue of whether someone is or is not guilty of racism, as was done in Bester CC, instead of considering it as a ground of mitigation or aggravation of the sanction, as in Khumalo, tilts the scales too much. That would not serve to promote cohesion between the different racial groups in South Africa.

\section{Bibliography}

\section{Literature}

Ackerman 2004 NZ L Rev

Ackerman LWH "The Legal Nature of the South African Constitutional Revolution" 2004 NZ L Rev 633-680

Basson et al New Essential Labour Law Handbook

Basson AC et al The New Essential Labour Law Handbook $6^{\text {th }}$ ed (Labour Law Publications Centurion 2017)

Bekink Principles of South African Constitutional Law

Bekink B Principles of South African Constitutional Law $2^{\text {nd }}$ ed (LexisNexis Durban 2016)

Botha 2018 THRHR

Botha MM "Managing Racism in the Workplace" 2018 THRHR 671-681

Botha and Govindjee 2017 PELJ

Botha JC and Govindjee A "Hate Speech Provisions and Provisos: A Response to Marais and Pretorius and Proposals for Reform" 2017 PELJ 1-37 - DOI https://dx.doi.org/10.17159/1727-3781/2017/v20i0a1395

Carney 2014 Language Matters

Carney T "Being (Im)polite: A Forensic Linguistic Approach to Interpreting a Hate Speech Case" 2014 Language Matters: Studies in the African Languages of Africa 325-341 - DOI:10.1080/10228195.2014.959545

$265 \quad$ Khumalo para 102. 
Currie and De Waal Bill of Rights Handbook

Currie I and De Waal J The Bill of Rights Handbook $6^{\text {th }}$ ed (Juta Cape Town 2013)

Du Toit 2006 ILJ

Du Toit D "The Evolution of the Concept of Unfair Discrimination in South African Labour Law" 2006 ILJ 1311-1326

Friedman 2000 Ecquid Novi

Friedman S "Racism under Scrutiny" 2000 Ecquid Novi 267-268

Geldenhuys 2016 SA Merc LJ

Geldenhuys J "Inequality in Equality" 2016 SA Merc LJ 399-435

Geldenhuys 2019 TSAR

Geldenhuys $\mathrm{J}$ "The South African Human Rights Commission: A Last Lifebuoy or Pulling the Plug?" 2019 TSAR 640-667

Gutto Equality and Non-Discrimination in South Africa

Gutto S Equality and Non-Discrimination in South Africa: The Political Economy of Law and Law Making (New Africa Books Claremont 2001)

Herd 2019 PSLR

Herd N "Should the Flag Fit, or Must We Acquit?" 2019 PSLR 130-154

IRR Race Relations 2001

South African Institute of Race Relations Race Relations and Racism in Everyday Life - Fast Facts (IRR Johannesburg 2001)

IRR Race Relations 2016

South African Institute of Race Relations Race Relations in South Africa: Reasons for Hope 2016 (IRR Johannesburg 2016)

IRR Race Relations 2017

South African Institute of Race Relations Race Relations in South Africa: Reasons for Hope 2017 (IRR Johannesburg 2017)

IRR Race Relations 2019

South African Institute of Race Relations Race Relations in South Africa: Reasons for Hope 2019 (IRR Johannesburg 2019)

Khumalo 2018 SA Merc LJ

Khumalo B "Racism in the Workplace: A View from the Jurisprudence of Courts in the Past Decade" 2018 SA Merc LJ 377-394 
Kok 2009 SA Public Law

Kok $A$ "Which is the appropriate forum when hate speech occurs in the workplace: The equality court or the labour court? Strydom v Chiloane 2008 (2) SA 247 (T)" 2009 SA Public Law 651-658

Lawrence Beeld

Lawrence M "Bereik Skikking met die MRK" Beeld (30 August 2019) 10

Murray 2006 PELJ

Murray C "The Human Rights Commission et al: What is the Role of the Chapter 9 Institutions?" 2006 PELJ 121-147 - DOI: https://doi.org/10.17159/1727-3781/2006/v9i2a2819

Rosenfeld Hate Speech in Constitutional Jurisprudence Rosenfeld M Hate Speech in Constitutional Jurisprudence: A Comparative Analysis (Cardozo Law School New York 2001)

StatsSA Survey

Statistics South Africa Governance, Public Safety and Justice Survey (StatsSA Pretoria 2019)

\section{Case law}

Biggar v City of Johannesburg (Emergency Management Services) 201738 ILJ 1806 (LC)

Brink v Kitshoff 19964 SA 197 (CC)

Campbell Scientific Africa (Pty) Ltd v Simmers 201637 ILJ 116 (LAC)

Canada (Human Rights Comm.) v Taylor 199013 CHRR D/435 (SCC)

Catch the Fire Ministries Inc v Islamic Council of Victoria 2006 VSCA 248; 200615 VR 207, 249 [132]

City Council of Pretoria v Walker 19982 SA 363 (CC)

City of Cape Town v Freddie 201637 ILJ 1364 (LAC)

Council for Scientific and Industrial Research v Fijen 19962 SA 1 (SCA)

Crown Chickens (Pty) Ltd t/a Rocklands Poultry v Kapp 20026 BLLR 493 (LAC)

De Lange v Smuts 19983 SA 785 (CC) 
Dolo v Commission for Conciliation, Mediation and Arbitration 201132 ILJ 905 (LC)

Duncanmec (Pty) Limited v Gaylard 20186 SA 335 (CC)

Dyonashe v Siyaya Skills Institute (Pty) Ltd 20183 BALR 280 (CCMA)

Edcon Ltd v Pillemer 200930 ILJ 2642 (SCA)

Freedom Front $v$ South African Human Rights Commission 200311 BCLR 1283 (SAHRC)

Gordon v National Oilwell Varco 20179 BALR 935 (MEIBC)

Hagan v Trustees of the Toowoomba Sports Grounds Trust 2000 FCA 1615

Harksen v Lane 19981 SA 300 (CC)

Herselman $v$ Geleba (ECG) (unreported) case numbers 231/2009, 1-92011; 2011 ZAEQC 1

Hoescht (Pty) Ltd v Chemical Workers Industrial Union 199314 ILJ 1449 (LAC)

Hotz v University of Cape Town 20172 SA 485 (SCA)

Institute for Democracy in SA v African National Congress 200510 BCLR $995(C)$

Islamic Unity Convention v Independent Broadcasting Authority 20024 SA 294 (CC)

Lebowa Platinum Mines Ltd v Hill 199819 ILJ 1112 (LAC)

Makhanya v St Gobain 20197 BALR 720 (NBCCl)

Mangope v Asmal 19974 SA 277 (T)

Media 24 Ltd v Grobler 20053 All SA 297 (SCA)

Minister of Finance $v$ Van Heerden 20046 SA 121 (CC)

Minister of Health v New Clicks SA (Pty) Ltd 20062 SA 311 (CC)

National Coalition of Gay and Lesbian Equality v Minister of Justice 19991 SA 6 (CC) 
Nelson Mandela Foundation Trust v AfriForum 20196 SA 327 (GJ)

President of the Republic of South Africa v Hugo 1998 JOL 1543 (CC)

Qwelane v South African Human Rights Commission 20202 SA 124 (SCA)

$R v$ Malik 19681 All ER 582

Rustenburg Platinum Mine v SAEWA obo Bester 20185 SA 78 (CC)

S v Makwanyane 19943 SA 868 (A)

S v Makwanyane 19953 SA 391 (CC)

S v Mhlungu 19953 SA 391 (CC)

SA Commercial Catering and Allied Workers Union obo Sikhundla and Radisson BluHotel Waterfront 201031 ILJ 1500 (CCMA)

SA Equity Workers Association obo Bester v Rustenburg Platinum Mine 201738 ILJ 1779 (LAC)

SAEWU v Rustenburg Platinum Mines (LAC) case number JA 45/2016 of 3 May 2017

South African Breweries (Pty) Ltd v Hansen 201738 ILJ 1766 (LAC)

South African Human Rights Commission v Khumalo 20191 SA 289 (GJ)

South African Revenue Service v Commission for Conciliation, Mediation and Arbitration 201738 ILJ 97 (CC)

Stokwe v MEC, Department of Education, Eastern Cape Province 20058 BLLR 822 (LC)

Strydom v Chiloane 20082 SA 247 (T)

Thembani $v$ Swanepoel 20173 SA 70 (ECM)

Vodacom v Byrne 201233 ILJ 2705 (LC)

\section{Legislation}

Bantu Education Act 47 of 1953

Constitution of the Republic of South Africa 200 of 1993 
Constitution of the Republic of South Africa, 1996

Employment Equity Act 55 of 1998

Labour Relations Act 66 of 1995

Native Laws Amendment Act 54 of 1952

Prevention and Combating of Hate Crimes and Hate Speech Bill B9-2018

Promotion of Equality and Prevention of Unfair Discrimination Act 4 of 2000

South African Human Rights Commission Act 40 of 2013

Suppression of Communism Act 44 of 1950

\section{Government publications}

Gen N 167 in GG 41543 of 29 March 2018 (Explanatory Summary of the Prevention and Combating of Hate Crimes and Hate Speech Bill, 2018)

\section{International instruments}

International Convention on the Elimination of All Forms of Racial Discrimination (1965)

\section{Internet sources}

AfriForum 2018 https://www.afriforum.co.za/en/afriforum-welcomesdismissal-major-mohlala-hate-speech/

AfriForum 2018 AfriForum Welcomes Dismissal of Major Mohlala after Hate Speech https://www.afriforum.co.za/en/afriforum-welcomes-dismissalmajor-mohlala-hate-speech/ accessed 17 August 2019

AfriForum $2019 \mathrm{https}: / /$ allafrica.com/stories/201906170365.html AfriForum 2019 Press Release - South Africa: AfriForum Asks Minister Pandor to Dismiss Ambassador Zindzi Mandela after Divisive Tweets https://allafrica.com/stories/201906170365.html accessed 14 August 2019

Agency 2016 https://mg.co.za/article/2016-03-15-standard-banks-chrishart-resigns

Agency 2016 "Standard Bank's Chris Hart Resign" Mail \& Guardian (15 March 2016) https://mg.co.za/article/2016-03-15-standard-banks-chrishart-resigns accessed 17 August 2019 
Anon 2016 https://www.enca.com/south-africa/penny-sparrow-feels-twitterwrath

Anon 2016 "PennySparrowMustFall: Estate Agent Feels Twitter Wrath after Racist Post" eNCA (4 January 2016) https://www.enca.com/southafrica/penny-sparrow-feels-twitter-wrath accessed 17 August 2019

Anon 2019 https://www.enca.com/life/multichoice-bans-all-of-stevehofmeyrs-music

Anon 2019 "MultiChoice Bans Steve Hofmeyr's Music" eNCA (30 April 2019) https://www.enca.com/life/multichoice-bans-all-of-steve-hofmeyrsmusic accessed 18 July 2019

Anon 2019 https://www.zimeye.net/2019/06/18/latest-on-zindzi-mandelaland-thieves-tweet/\#

Anon 2019 Latest on Zindzi Mandela 'Land Thieves' Tweet https://www.zimeye.net/2019/06/18/latest-on-zindzi-mandela-land-thievestweet/\# accessed 18 June 2019

Bosman 2019 https://maroelamedia.co.za/debat/meningsvormers/mense regtekommissie-skeer-nie-almal-oor-dieselfde-kam/

Bosman J 2019 "Menseregtekommissie Skeer nie Almal oor Dieselfde Kam" Maroela Media (16 July 2019) https://maroela media.co.za/debat/meningsvormers/menseregtekommissie-skeer-niealmal-oor-dieselfde-kam/ accessed 1 September 2019

Bozzoli 2018 https://www.dailymaverick.co.za/opinionista/2018-11-13what-happens-when-universities-start-to-decay-the-case-of-unisa/ Bozzoli B 2018 What Happens when Universities Start to Decay: The Case of Unisa https://www.dailymaverick.co.za/opinionista/2018-11-13-whathappens-when-universities-start-to-decay-the-case-of-unisa/ accessed 17 August 2019

Brink and Mulder 2017 https://solidariteit.co.za/wp-content/ uploads/2017/10/Racism-hate-speech-and-double-standards-by-nomeans-a-mere-matter-of-bla....pdf

Brink E and Mulder C 2017 Racism, Hate Speech and Double Standards: Not a Simple Black and White Matter https://solidariteit.co.za/wpcontent/uploads/2017/10/Racism-hate-speech-and-double-standards-byno-means-a-mere-matter-of-bla....pdf accessed 19 July 2019 
Burger 2016 https://nuus.info/dosent-na-wit-kokkerotte-nog-ongestraf/ Burger A 2016 Dosent na 'Wit Kokkerotte' nog Ongestraf https://nuus.info/dosent-na-wit-kokkerotte-nog-ongestraf/ accessed 1 September 2019

Burger 2016 https://www.netwerk24.com/Nuus/Politiek/ernstig-gewaarskuoor-wit-kakkerlakke-20161022

Burger A 2016 "Ernstig Gewaarsku oor 'Wit Kakkerlakke"' Netwerk24 (23 October 2016) https://www.netwerk24.com/Nuus/Politiek/ernstiggewaarsku-oor-wit-kakkerlakke-20161022 accessed 1 September 2019

Cilliers 2020 https://citizen.co.za/news/south-africa/courts/2237551/peterpaul-ngwenya-fined-r24k-suspended-for-use-of-k-word-on-investecs-ceo/ Cilliers C 2020 "Peter-Paul Ngwenya Fined R24K, Suspended, for Use of K-word on Investec's CEO" The Citizen (7 May 2020) https://citizen.co.za/news/south-africa/courts/2237551/peter-paulngwenya-fined-r24k-suspended-for-use-of-k-word-on-investecs-ceo/ accessed 3 June 2020

Cornelissen 2019 https://maroelamedia.co.za/nuus/sa-nuus/klagte-teenzindzi-mandela-by-menseregtekommissie-ingedien/

Cornelissen C 2019 "Klagte teen Zindzi Mandela Ingedien by die Menseregtekommissie" Maroela Media (18 July 2019) https://maroelamedia.co.za/nuus/sa-nuus/klagte-teen-zindzi-mandela-bymenseregtekommissie-ingedien/ accessed 14 August 2019

Ghoema Musiek Trust 2019 http://ghoema.co.za/

Ghoema Musiek Trust 2019 Verklaring, 17 April 2019 http://ghoema.co.za/ accessed 6 September 2019

Hlatshaneni 2019 https://citizen.co.za/news/south-africa/general/ 2119286/my-combi-court-rant-wasnt-racist-mazibuko-tells-sahrc/ Hlatshaneni S "My 'Combi-court' Rant wasn't Racist, Mazibuko Tells SAHRC" The Citizen (17 April 2019) https://citizen.co.za/news/southafrica/general/2119286/my-combi-court-rant-wasnt-racist-mazibuko-tellssahrc/ accessed 20 April 2019

IRR 2017 https://www.politicsweb.co.za/documents/against-the-hate-billthe-irrs-full-submission

South African Institute of Race Relations 2017 Against the Hate Bill: The IRR's Full Submission https://www.politicsweb.co.za/opinion/against-thehate-bill-the-irrs-full-submission accessed 5 June 2019 
Jana 2019 https://www.politicsweb.co.za/documents/malemas-whiteslaughter-remarks-the-sahrcs-finding

Jana P 2019 Malema's White Slaughter Remarks: The SAHRC's Finding https://www.politicsweb.co.za/documents/malemas-white-slaughterremarks-the-sahrcs-finding accessed 8 March 2019

Jordaan 2019 https://select.timeslive.co.za/news/2019-08-23-final-wordon-the-k-word-its-not-ok-whether-youre-black-or-white/

Jordaan N 2019 "Final Word on the K-word in Black and White" Times Select (23 August 2019) https://select.timeslive.co.za/news/2019-08-23final-word-on-the-k-word-its-not-ok-whether-youre-black-or-white/ accessed 30 August 2019

Jordaan 2019 https://www.sowetanlive.co.za/news/south-africa/2019-0523-k-word-can-be-offensive-only-when-used-by-whites-says-ngwenyaslawyer/

Jordaan N 2019 "K-word can be Offensive only when Used by Whites, Says Ngwenya's Lawyer" Sowetan Live (23 May 2019) https://www.sowetanlive.co.za/news/south-africa/2019-05-23-k-word-canbe-offensive-only-when-used-by-whites-says-ngwenyas-lawyer/ accessed 17 August 2019

Jordaan 2019 https://www.timeslive.co.za/news/south-africa/2019-07-16judgment-in-businessmens-k-word-spat-to-be-delivered-in-august/ Jordaan N 2019 "Judgment in Businessmen's K-word Spat to be Delivered in August" Sunday Times (19 July 2019) https://www.timeslive.co.za/news/south-africa/2019-07-16-judgment-inbusinessmens-k-word-spat-to-be-delivered-in-august/ accessed 19 July 2019

Kaunda 2019 https://citizen.co.za/news/south-africa/social-media/2137223/ afriforum-wants-multichoice-to-pull-a-steve-hofmeyr-on-ntsiki-mazwai/ Kaunda, S 2019 "AfriForum wants Multichoice to Pull a Steve Hofmeyr on Ntsiki Mazwai" The Citizen (30 May 2019) https://citizen.co.za/news/southafrica/social-media/2137223/afriforum-wants-multichoice-to-pull-a-stevehofmeyr-on-ntsiki-mazwai/ accessed 5 June 2019

Lindeque 2019 https://ewn.co.za/2018/08/22/adam-catzavelos-fired-fromfamily-business-after-racist-video

Lindeque M 2018 "\#Adamcatzavelos Fired from Family Business after Racist Video, Nike Responds" Eyewitness News (22 August 2018) 
https://ewn.co.za/2018/08/22/adam-catzavelos-fired-from-family-businessafter-racist-video accessed 24 July 19

Mabuza and Gous 2019 https://www.timeslive.co.za/news/southafrica/2018-08-22-family-sorry-for-hurt-caused-by-catzavelos-as-deaththreats-are-made/

Mabuza E and Gous N 2018 "Family Sorry for Hurt Caused by Adam Catzavelos as Death Threats are Made" Times Live (22 August 2018) https://www.timeslive.co.za/news/south-africa/2018-08-22-family-sorry-forhurt-caused-by-catzavelos-as-death-threats-are-made/ accessed 24 July 2019

Mahamba 2019 https://www.iol.co.za/the-star/news/why-would-an-exrobben-islander-call-another-black-person-a-kr-14628934

Mahamba C 2019 "Why would an Ex-Robben Islander Call Another Black Person a K ${ }^{\star \star * *} r$ ?" The Star (24 April 2019) https://www.iol.co.za/thestar/news/why-would-an-ex-robben-islander-call-another-black-person-akr-14628934 accessed 17 August 2019

Maroela Redaksie 2019 https://maroelamedia.co.za/nuus/sa-nuus/effbeaam-zindzi-mandela-se-uitlatings/

Maroela Redaksie 2019 "EFF Beam Zindzi Mandela se Uitlatings" Maroela Media (18 Junie 2019) https://maroelamedia.co.za/nuus/sa-nuus/effbeaam-zindzi-mandela-se-uitlatings/ accessed 14 August 2019

Maughan 2019 https://www.businesslive.co.za/bd/politics/2019-08-07helen-zille-and-busisiwe-mkhwebane-to-square-off-over-colonialismtweets/

Maughan K "Mkhwebane and Zille to Slug it out over Colonialism Tweets Ruling" Financial Mail (7 August 2019) https://www.businesslive. co.za/bd/politics/2019-08-07-helen-zille-and-busisiwe-mkhwebane-tosquare-off-over-colonialism-tweets/ accessed 1 September 2019

Mawson 2016 https://www.iol.co.za/business-report/companies/who-ischris-hart-1966769

Mawson N 2016 "Who is Chris Hart?" IOL (5 January 2016) https://www.iol.co.za/business-report/companies/who-is-chris-hart1966769 accessed 17 August 2019

Natasha Stop White Genocide in SA 2016 https://stopwhitegenocideinsareports.blogspot.com/2016/06/black-unisalecturer-who-called-white.html 
Natasha Stop White Genocide in SA 2016 Black UNISA Lecturer Who Called White People \#Cockroaches Remains Unpunished https://stopwhitegenocideinsareports.blogspot.com/2016/06/black-unisalecturer-who-called-white.html accessed 2 August 2019

Nkosi 2019 https://www.iol.co.za/the-star/news/peter-paul-ngwenyasdefence-of-black-on-black-slur-disingenuous-court-hears-23830007

Nkosi B 2019 "Peter-Paul Ngwenya's Defence of Black-on-black Slur Disingenuous, Court Hears" IOL (23 May 2019) https://www.iol.co.za/thestar/news/peter-paul-ngwenyas-defence-of-black-on-black-slurdisingenuous-court-hears-23830007 accessed 17 August 2019

O'Grady 2015 https://foreignpolicy.com/2016/04/15/rwandan-who-calledtutsis-cockroaches-in-1992-gets-life-sentence/

O'Grady S 2015 Rwandan Who Called Tutsis 'Cockroaches' in 1992 Gets Life Sentence https://foreignpolicy.com/2016/04/15/rwandan-who-calledtutsis-cockroaches-in-1992-gets-life-sentence/ accessed 2 August 2019

Okoye 2019 https://citizen.co.za/news/south-africa/investigation/ 2165938/bolhuis-mum-as-show-cancelled-over-alleged-racial-slurs/

Okoye CJ 2019 "Bolhuis Mum as Show Cancelled over Alleged Racial Slurs" The Citizen (12 August 2019) https://citizen.co.za/news/southafrica/investigation/2165938/bolhuis-mum-as-show-cancelled-overalleged-racial-slurs/ accessed 14 August 2019

Oxford Pro Bono Publico 2012 https://www.law.ox.ac.uk /sites/files/oxlaw/1._comparative_hate_speech_-_Irc.pdf

Oxford Pro Bono Publico 2012 Comparative Hate Speech Law: Memorandum

https://www.law.ox.ac.uk/sites/files/oxlaw/1._comparative_hate_speech__Irc.pdf accessed 20 August 2019

Pienaar 2019 https://www.golegal.co.za/derogatory-language-workplace/ Pienaar H 2019 No more "Boers" Allowed in the Workplace!? https://www.golegal.co.za/derogatory-language-workplace/ accessed 17 August 2019

Ramphele 2019 http://www.capetalk.co.za/articles/297688/crime-andpunishment-vicki-momberg-s-landmark-sentence-explained

Ramphele L 2018 "Crime and Punishment: Vicki Momberg's Landmark Sentence Explained" Cape Talk 567 AM (29 March 2018) http://www.capetalk.co.za/articles/297688/crime-and-punishment-vickimomberg-s-landmark-sentence-explained accessed 19 July 2019 
SAHRC 2019 https://www.sahrc.org.za/home/21/files/SAHRC\%20Finding \%20Julius\%20Malema\%20\&\%200ther\%20March\%202019.pdf South African Human Rights Commission 2019 Findings Regarding Certain Statements Made by Mr Julius Malema and Another Member of the Economic Freedom Fighters https://www.sahrc.org.za/home/21/files/ SAHRC\%20Finding\%20Julius\%20Malema\%20\&\%20Other\%20March\%20 2019.pdf accessed 17 August 2019

SAHRC 2019 https://sahrc.org.za/index.php/sahrc-media/news/item/2030sahrc-will-consider-probe-into-zindzi-mandela-tweets

South African Human Rights Commission 2019 SAHRC 'will Consider' Probe into Zindzi Mandela Tweets https://sahrc.org.za/index.php/sahrcmedia/news/item/2030-sahrc-will-consider-probe-into-zindzi-mandelatweets accessed 14 August 2019

SAPeople 2018 https://www.sapeople.com/2018/03/29/reasons-must-beprovided-for-not-charging-major-over-racist-statements/

SAPeople 2018 "Defence Minister must Provide Reasons for not Charging Major over Racist Statements" SA People News (29 March 2018) https://www.sapeople.com/2018/03/29/reasons-must-be-provided-for-notcharging-major-over-racist-statements/ accessed 17 August 2019

Southern Africa Litigation Centre 2020 https://www.southernafricalitigation centre.org/2020/04/28/jonathan-dubula-qwelane-v-south-african-humanrights-commission-and-another/

Southern Africa Litigation Centre 2020 Jonathan Dubula Qwelane v South African Human Rights Commission and Another https://www.southern africalitigationcentre.org/2020/04/28/jonathan-dubula-qwelane-v-southafrican-human-rights-commission-and-another/ accessed 3 June 2020

Staff Reporter 2019 https://www.iol.co.za/news/politics/zindzimandeladivides-twitter-with-ourland-tweets-26346019

Staff Reporter 2019 "\#Zindzi Mandela Divides Twitter with \#OurLand Tweets" IOL (15 June 2019) https://www.iol.co.za/news/politics/ zindzimandela-divides-twitter-with-ourland-tweets-26346019 accessed 18 July 2019

UNHRC 2019 https://indicators.ohchr.org/

United Nations Human Rights Commission 2019 Status of Ratification, Reservations and Declarations - South Africa https://indicators.ohchr.org/ accessed 13 March 2019) 
Van Niekerk 2019 https://www.netwerk24.com/Stemme/Menings/hiermaak-die-mrk-droog-20190415

Van Niekerk A 2019 "Hier maak die MRK Droog" Beeld (16 April 2019) https://www.netwerk24.com/Stemme/Menings/hier-maak-die-mrk-droog20190415 accessed 20 April 2019

Venter 2020 https://www.netwerk24.com/Nuus/Hof/afriforum-kry-verlof-totappel-oor-ou-landsvlag-20200508

Venter I 2020 "AfriForum Appelleer Nou oor Vryheid van Spraak, nié oor Vlag" Netwerk24 (8 May 2020) https://www.netwerk24.com/ Nuus/Hof/afriforum-kry-verlof-tot-appel-oor-ou-landsvlag-20200508 accessed 3 June 2020

Zibi $2019 \quad$ https://www.msn.com/en-za/news/politicsvideo/dircoinvestigating-zindzi-mandela-tweets/ar-AAD3xvE

Zibi O 2018 DIRCO Investigating Zindzi Mandela Tweets https://www.msn.com/en-za/news/politicsvideo/dirco-investigating-zindzimandela-tweets/ar-AAD3xvE accessed 14 August 2019

\section{List of Abbreviations}

CCMA

EEA

EFF

ICERD

ILJ

IRR

LDD

LRA

NZ L Rev

PELJ

PEPUDA

PSLR

SAHRC

SA Merc LJ

SANDF

StatsSA

THRHR
Commission for Conciliation, Mediation and Arbitration

Employment Equity Act 55 of 1998

Economic Freedom Fighters

International Convention on the Elimination of

All Forms of Racial Discrimination

Industrial Law Journal

South African Institute of Race Relations

Law, Democracy and Development

Labour Relations Act 66 of 1995

New Zealand Law Review

Potchefstroom Electronic Law Journal

Promotion of Equality and Prevention of Unfair

Discrimination Act 4 of 2000

Pretoria Student Law Review

South African Human Rights Commission

South African Mercantile Law Journal

South African National Defence Force

Statistics South Africa

Tydskrif vir Hedendaagse Romeins-

Hollandse Reg 
TSAR

UNHRC
Tydskrif vir die Suid-Afrikaanse Reg

United Nations Human Rights Commission 